\title{
Releasing Constraints to Growth or Pushing on a String? The Impact of Credit, Training, Business Associations and Taxes on the Performance of Mexican Micro-Firms
}

\author{
Pablo Fajnzylber \\ The World Bank \\ William F. Maloney \\ The World Bank \\ Gabriel V. Montes Rojas \\ University of Illinois at Urbana-Champaign
}

\begin{abstract}
We employ propensity score matching and a traditional control function approach to examine the impact of participation in various societal institutions on micro-firm performance in Mexico. We find that firms that participate in credit markets, receive training, pay taxes and belong to business associations exhibit significantly higher profits, even after controlling for the various factors that drive participation in those institutions. We also find that firms that borrow from formal or informal sources and those that pay taxes are significantly more likely to stay in business, but firms that received credit exhibit lower rates of income growth. Overall, our results suggest that even if the best performing micro-firms are more likely to be selected into participating in societal institutions, causality also runs in the opposite direction. In particular, increases in strictly or broadly defined formality have the potential for increasing profits and survival rates, and appear to bring micro-firms closer to their optimal sizes.
\end{abstract}

World Bank Policy Research Working Paper 3807, January 2006

The Policy Research Working Paper Series disseminates the findings of work in progress to encourage the exchange of ideas about development issues. An objective of the series is to get the findings out quickly, even if the presentations are less than fully polished. The papers carry the names of the authors and should be cited accordingly. The findings, interpretations, and conclusions expressed in this paper are entirely those of the authors. They do not necessarily represent the view of the World Bank, its Executive Directors, or the countries they represent. Policy Research Working Papers are available online at http://econ.worldbank.org. 


\section{Introduction}

Micro-firms account for roughly $50 \%$ of employment in Latin America and substantially more in Africa and Southeast Asia. Raising their productivity therefore ranks high as a development goal and eliminating impediments to their dynamism as a central concern of policy. Using a very detailed micro-firm data set with a panel dimension from Mexico, this paper examines how micro firm performance is affected by several dimensions of their business environment: access to formal and informal credit, training programs, business associations or guilds, and government taxation and services. Following the convention of the literature on evaluation in quasi-experimental contexts, we conceive of engaging with these institutions as treatments and attempt to measure their impact.

In our sample the share of treated firms is low: less than $10 \%$ of micro-firms have received credit or training services and less than $17 \%$ participate in industry or trade associations. This is often seen as evidence of supply bottlenecks that limit access to financing, human capital, and information. Releasing those constraints would permit firms to approach the steady state size dictated by their intrinsic entrepreneurial ability. ${ }^{1}$ However, it may also be that for many firms, the steady state size is very small and thus there is, in fact, little demand for these treatments. For example, a sizable literature dating from Harris and Todaro (1970) argues that most informal micro-firms are run by individuals who did not enter the sector due to their higher entrepreneurial ability or other cost advantages, but rather are essentially queuing for entry into salaried jobs and are unlikely to be thinking of future growth. In sum, while in one approach increasing the supply of credit, training and information services would lead to improved business performance, in the other it would amount to pushing on a string and have little impact.

Empirically, estimating the magnitude of any treatment impact is not trivial. Both views imply self selection into the treatments considered which potentially imparts serious bias to naïve ordinary least squares (OLS) estimates. As an example, applying for

\footnotetext{
${ }^{1}$ In Lucas'(1978) model, for instance, factors such as location and entrepreneurial ability determine firmspecific costs structures and optimal firm sizes. Newly created firms would tend to converge to their steady state sizes, provided that they are not supply-constrained in their access to factor or goods markets.
} 
bank credit, seeking out training, and joining a business association could all reflect superior underlying entrepreneurial ability, rather than any impact of the treatment.

The final dimension of the business environment - payment of at least some taxes (31\% in our sample)- is the most common indicator of "informality" in the literature and poses a particularly interesting treatment with potentially distinct selection issues. One literature views informality as evasion of taxes (for example, Loayza, 1996): firms that pay them do so because they had the bad luck of being detected by government. However, tax payments may be also seen as the cost of gaining access to social services that are necessary for the expansion of businesses. For instance, as de Soto (1989) pointed out in the case of Peruvian street vendors, weak property rights made expanding risky and the vendors actively sought to pay their taxes to gain "quasi-property rights" over their respective pitches. More generally, registration with the government makes it possible to engage in legal contracts, participate in risk pooling and worker insurance mechanisms, and borrow from formal financial institutions. ${ }^{2}$ Treatment, in this second view, would yield a positive impact on firm performance, and it would be subject to the same selection problems that affect the estimation of the treatment effects of access to credit, training and participation in business associations.

To minimize the potential estimation biases arising from the self-selection of firms into the various treatments, we employ two different techniques and three different sets of conditioning variables. After reporting naïve OLS estimates as a first approximation, we focus on Propensity Score Matching, a method that thanks to the advantage of being non-parametric has become increasingly popular in recent years. ${ }^{3}$ Its main shortcoming, however, is that it models selection into treatment as depending only on observable variables. This may lead to biased estimates if there are unmeasurable individual characteristics - e.g. unobserved entrepreneurial ability - that affect both the likelihood of treatment and the associated outcomes. Thus, we also use a conventional control function approach that seeks explicitly to model the selection on unobservables,

\footnotetext{
2 As one all encompassing view, Levenson and Maloney (1996) recast the question of formality/informality as the firm's decision of how much to participate or engage in the institutions of civil society: federal and local treasuries, governmental programs such as social security, the legal system, the banking system, trade organizations, civic organizations, etc. This view is consistent with the emerging literature on social capital and networks that views formal and informal services as substitutes. See, for example Portes and Landolt (2000) and Stiglitz (2000). Tybout (2000) provides an excellent literature review on this topic.

${ }^{3}$ For a review of this literature see Heckman, LaLonde and Smith (1999) and Imbens (2004). For recent work in the developing countries context see, for example, Jalan and Ravallion (2003), Newman et al. (2002) and Galasso, Ravallion and Salvia (2001).
} 
even if in the process it imposes strong assumptions on the functional forms of the selection and outcome equations. As Heckman and Navarro-Lozano (2004) argue, the two techniques are closely related and matching can be seen as a special case of control function methods where the former assumes that conditioning eliminates bias through the “conditional independence assumption” (CIA) whereas control function methods explicitly model selection bias. In this approach, the preference for one or the other method cannot be driven by their intrinsic technical advantages, but rather should be based on a judgment on which choice of underlying assumptions is most plausible.

As further robustness checks, with both methods we control for selection on an increasingly rich set of firm characteristics. At least in the case of propensity score matching, this brings us progressively closer to satisfying the CIA. The trade off is that since these variables may be correlated with both treatments and outcomes, we may also be progressively foreclosing channels through which the treatment may be working. This sequential approach arguably yields upper bounds that may be potentially affected by selection biases arising from unobservables, and lower bounds that are not, but which may miss some of the influence of the treatment.

As a final set of checks against bias, in the matching exercise, we test for the problem of non overlapping supports (identified by Heckman, Ichimura and Todd, 1998 as the largest source of bias) and we follow Rosenbaum and Rubin (1983b) in checking for the validity of the CIA. We also check the sensitivity of all estimates to the use of an alternative measure of firm profits.

In the final section of the paper, we utilize the panel dimension of the data to look at the impact of credit, training, taxes and guild membership on firm growth and survival. Here the self-selection problem is less serious since we can include initial income in the set of conditioning variables, thus arguably capturing a wider set of unobservables that affect treatment participation.

The paper is organized as follows. Section II presents the different methodologies and discusses the assumptions that allow us to use them. Section III describes the data. Section IV presents the estimations for the probability of participation and treatment effects. Finally, conclusions are presented in the last section. 


\section{Methodological Details}

Several options exist for estimating the impact of these treatments on firm performance. Very generally, we want to estimate

(1) $Y_{d}=g_{d}\left(X_{d}, U_{d}\right) \quad d=0,1$

where $d$ indexes the occurrence of a certain treatment (whose random variable will be denoted by $\mathrm{D} \in\{0,1\}), Y_{d}$ denotes an outcome of interest, and $X$ and $U$ are observable and unobservable characteristics of the firm. Again, we can associate treatment with the formal status of the firm: taking out a bank loan may lead to upgrading of accounting procedures, greater efficiency of capital and higher profits; joining a business association may introduce the entrepreneur to new technologies of ways of doing business; training workers may also lead to greater efficiency in the use of capital and labor. We can define $Y_{1}$ to be the outcome if the firm is exposed to the treatment of interest and $Y_{0}$ to be the outcome if the firm was untreated. For a given individual $i$, the observed outcome $Y_{i}$ can be written $Y_{i}=Y_{0 i}+D_{i}\left(Y_{1 i}-Y_{0 i}\right)$. The fundamental problem, of course, is the inability to observe the same individual both with and without treatment effects. Although this problem cannot be solved at the level of any individual, we can identify the average treatment effect of the population. Parameters that only depend on the marginal distribution of $Y_{1 \mathrm{i}}$ and $\mathrm{Y}_{0 \mathrm{i}}$ are the 'average treatment effect' (ATE) $E\left(Y_{1}-Y_{0}\right)$, the average treatment effect on the non-treated' $E\left(Y_{1}-Y_{0} \mid D=0\right)$ and the 'average treatment effect on the treated' (ATT) $E\left(Y_{1}-Y_{0} \mid D=1\right)$. The last is the effect of most interest in the literature.

\section{Matching techniques}

Though numerous arguments have been put forward for using matching techniques, their most attractive quality is perhaps not imposing functional relationships between the treatment and the outcome. Matching techniques effectively create a pseudo control group with observable characteristics that are arbitrarily "similar" to the "treated" group. 
In practice, matching techniques use one of several possible distance measures to find observations that are "close" to those in the control group. As the set of characteristics that are taken into account increases, and/or if they contain continuous variables, the number of observations in each cell to be matched gets very small (or null). Alternatively put, it becomes difficult to find individuals with traits that appropriately match those of the treated in all relevant dimensions. One popular solution is that of basing the matching of treated and controls on the conditional predicted probability of participating in the program - the so-called propensity score $P(x)=\operatorname{Pr}\{D=1 \mid X=x\}$ the conditional probability of participation given a vector of observed characteristics $x$. Rosenbaum and Rubin (1983a) show that, by definition the treatment and non-treatment observations with the same value of the propensity score have the same distribution of the full vector of regressors $X$ and it is therefore sufficient to match exactly on the propensity score ${ }^{4}$ - a single variable on the unit interval- to obtain the same probability distribution of $X$ for treated and non-treated individuals. This variable should contain all the information in $X$ relevant for the $\mathrm{ATT}^{5}$. In practice, the propensity score can be derived parametrically from either probit or logit methodologies.

What is important is that these average effects are the reduced form impacts arriving through any number of channels of unspecified functional form: we do not impose any functional restrictions on $g($.), nor do we need a set of excluded variables to identify it. Matching offers a very flexible non-parametric form of estimating the impact of a treatment.

However, the validity of the matching estimators relies on the CIA, which states that conditional on the $X$ 's used to match, the control group does not differ from the treatment group by any variable which is systematically linked to the non-participation outcome $Y_{0}$ : That is the selection is on observables (Heckman and Robb, 1985). In short, the CIA can be expressed as:

$$
Y_{0} \perp D \mid X
$$

\footnotetext{
${ }^{4}$ An additional requirement for propensity score matching is: $0<P(x)<1 \quad \forall \mathrm{x} \in \mathrm{X}$.

${ }^{5}$ According to Heckman, Ichimura and Todd (1998), if the outcome depends on $X$ only through $P(X)$, there is no advantage to conditioning on $X$ over conditioning on $P(X)$. Condition on the propensity score has some advantages over covariate-matching methods. According to Imbens (1999) inference for ATT is less sensitive to specifications of the propensity score than on covariates. Angrist and Hahn (1999) show that for some plausible scenarios (such as small cell-sizes and probability of treatment far from $1 / 2$ ) propensity score matching estimators could be more efficient than exact-matching ones.
} 
where $\perp$ denotes stochastic independence. Heckman, Ichimura and Todd (1998) demonstrated that a weaker assumption, “conditional mean independence” (CMI), is in fact sufficient:

$$
E\left(Y_{0} \mid X, D=1\right)=E\left(Y_{0} \mid X, D=0\right)
$$

How innocuous the CIA (or the simpler CMI) is depends on how much we believe that unobserved variables are irrelevant to both the likelihood of treatment and the outcome realization. The concern that the CIA may not hold is not particular to the present application but extends to the myriad papers on the impact of active labor market policies as well: to the degree that ambitious or talented workers self-select into training programs, we may confound superior job market performance due to unobserved human capital with the impact of the treatment.

\section{Growth}

Alternatively, if we have at least two periods for the same individual, by looking at the behavior of second period income, we can capture the dynamic effect of treatment instead of the static levels effect analyzed in the first part of the paper. Suppose that two periods are available for each individual $\left(t^{\prime}>t\right)$ and define:

$$
\begin{aligned}
& \text { (4) } \quad R_{1}=Y_{1}\left(t^{\prime}\right)-Y_{1}(t) \\
& \text { (5) } \quad R_{0}=Y_{0}\left(t^{\prime}\right)-Y_{0}(t)
\end{aligned}
$$

Note that the first period outcome variable can be considered part of the selection process and hence can be included as a covariate in the propensity score. More specifically let $\hat{X}=X \cup\left(Y_{0}(t) \cup Y_{1}(t)\right)$ and further define $E\left(R_{1}-R_{0} \mid D=1\right)$ as the parameter of interest, that is the average treatment effect on the treated measured. If $\mathrm{Y}$ is in logs, this can be interpreted as the average treatment effect on the treated on growth (ATTG). Using the same arguments that we used before, matching analysis requires:

$$
R_{0} \perp D \mid \hat{X}
$$

In this panel context, assumption (6) is more defensible than its levels counterpart. If we assume that the information about future growth is contained in present period profits 
conditional on the other controls in the propensity score, as is the case in Jovanovic's (1982) noisy selection framework, then we are likely to be controlling for the fact that a higher expected level of growth will affect the desire for treatment. Whether or not the treatment is available would then determine the eventual growth outcome. ${ }^{6}$

The ATTG can be interpreted as the effect of the treatment on outcome growth conditional on starting with the same level of outcome and regressors at $t$. Clearly, this controls for any impact that treatment has had in the past on growth. However, the same logic appears in cross-country growth regressions where obtaining the rate of growth requires conditioning on the initial level of income. The interpretation should be about whether the treatment had a permanent income effect on growth rates vs. the one off impact that appears in the levels regressions above.

\section{Survival}

The treatments may also affect the likelihood of survival, rather than the growth of the firm. To analyze this explicitly let $S$ be an outcome dummy variable that takes value 1 if the micro-firm survives and 0 otherwise. As before, we can condition on the treatment occurrence to construct $\mathrm{S}_{0}$ and $\mathrm{S}_{1}$. Matching procedures allow us to construct a non-parametric estimate of the effect of various treatments on the probability of firm survival. In a parallel way as we proceeded before, the assumption required is:

$$
S_{0} \perp D \mid \hat{X}
$$

${ }^{6}$ We still have a missing data problem that requires an additional assumption:

$P\left(X, Y_{0}(t), Y_{1}(t)\right)=P(X, Y(t))$

That is the actual level of income and the covariates $X$ are sufficient for obtaining the propensity score. This posses additional concerns similar to the inclusion of covariates which may themselves be affected by the treatment (see below) because we will be able to observe the initial income only in one treatment status 
Note that the conditioning variables also include the initial level of income, which, again, is likely to capture further unobserved firm characteristics that affect both the probability of being treated and the likelihood of firm survival.

\section{The propensity score}

Following Dehejia and Wahba (1999) matching estimation is done in two steps. First, we estimate the propensity score by probit models. Selection of the variables that determine the propensity score is an important issue. As Heckman, Ichimura and Todd (1997) argue, $X$ should contain those variables such that assumption (1) is satisfied but the prediction should not be "excessively good" (i.e. that predicts $D$ perfectly). Extremely different distributions of the predicted propensity score by treatment status would make it difficult to find comparable individuals, and this is a major source of evaluation bias. Endogenous regressors are potentially problematic if the treatment makes the support of treated and non-treated disjoint. We examine this possibility in detail in Appendix II, where we also examine, for the main covariates, the impact that the potential presence of non-overlapping support may have on post-matching bias.

Two matching procedures are used in this paper. First, we compute Nearest Neighbor estimates, and second, we apply a Kernel based method using Epanichnikov kernel and a fixed bandwidth of 0.06. In both cases, we compute estimates with and without the common support restriction on the domain of the propensity score.

\section{Expanding the Conditioning Set to Deal with Unobservables}

As a robustness check, we follow Rosenbaum and Rubin (1983b) and observe the sensitivity of the results as progressively more covariates are added to the first stage model of the determinants of being treated. In practice we start by including in the propensity score only those variables of $X$ which can credibly be considered exogenous to the treatment, namely a set of individual characteristics $H$. Since the excluded regressors may have a positive correlation with the outcome, these estimates are therefore likely to provide an upper bound to the treatment effect. We then add to the first stage propensity score model a set of variables $Z$ which are likely to control for unobservables but are also likely to be affected by the treatment. These variables are the firm's capital stock, number of workers and time in business. Finally in the third set of conditioning variables, we add 
the set of other treatment variables $(F)$. We interpret the corresponding estimates as capturing not only additional unobservables that may drive both firm performance and participation in various societal institutions, but also isolating the pure effect of each treatment from others with which it might be correlated.

As mentioned above, one concern is that some of the variables included in the second and third set of conditioning variables may be endogenous. As argued by Heckman, Ichimura, Smith and Todd (1998), the exogeneity of the conditioning set $X$ is not strictly required for matching methods, but the real treatment effect is masked if this condition is violated. If the treatment has a positive impact on these regressors, this estimation will understate the impact of the treatment, and it will constitute a lower bound. Indeed, we are excluding the treatment effect that operates through the regressors of the propensity score model, so that the estimated treatment effects are in practice conditional on these other regressors not changing. Thus, for instance, when we add employment size, and capital stocks to the $X$ vector, we are effectively measuring not the total effect of our treatments on firm profits, but rather the effects on the efficiency with which existing factors of production are used by similar treated and non-treated microfirms. $^{7}$

An additional concern is the possible non-overlapping support of conditioning variables which, as shown by Heckman, Ichimura and Todd (1998), is an important potential source of bias for matching methods. To check whether this is indeed a problem in our case we examine the generated distributions of the propensity score for treated and non-treated firms, and evaluate the post-matching bias in the main covariates.

\section{The Control Function Approach}

As argued by Heckman, LaLonde and Smith (1999) the standard treatment effects regression has the important advantage of allowing for selection on unobservables and hence not requiring the relatively strong CIA assumption underlying matching methods. As is generally well known, control function approaches introduce to eq. (1) an additional selection equation describing a latent variable $D^{*}$, such that the treatment occurs if $D^{*>0}$

\footnotetext{
${ }^{7}$ Implicitly we assume the existence of two different ways through which the treatment affects the outcome. First, a direct effect which is the result of buying a new equipment in the case of credit or increasing labor productivity in training. Second, an indirect effect, related to the impact on the firm's market performance and efficiency. Using regressors affected by the outcome may restrict our estimates to the latter.
} 
only. If $X$ can be partitioned into two not necessarily disjoint sets $(Q, T)$ such that $Q$ affects the outcome equation while $T$ determines the selection part it is possible to estimate the following model:

Outcome equation: $Y=g(Q)+\delta D+u$

Selection equation: $D^{*}=h(T)+v$

where $D=1$ if $D^{*>0}$ and $D=0$ otherwise. Selection bias is then treated as an omitted variable problem. As is common, linearity is assumed in the $g$ and $h$ functions. This set up imposes a much stricter parameterization on the outcome equation than matching does and than we would prefer since we think that treatment may be accompanied by changes in the production process. In our case no justifiable exclusion restrictions can be found to separate $\mathrm{Q}$ and $\mathrm{T}$ and therefore semiparametric estimators cannot identify $\mathrm{g}(.)^{8}$. Imposing assumptions about the joint distribution of $u$ and $v$, i.e. that they follow a bivariate normal distribution offers another alternative although Heckman, Tobias and Vytlacil (2000) have shown that distributional misspecification in this setting can impart important bias.

\section{Data}

We employ the National Survey of Microfirms (Encuesta Nacional de Micronegocios, ENAMIN) for the years 1992, 1994, 1996 and 1998. This survey covers a sample of individuals who declare that they are self-employed in a broader labor survey, the Encuesta Nacional de Empleo Urbano (ENEU). It is restricted to micro-firms with at most 6 workers (including owners) for all economic sectors except manufacturing where the range is from 1 to 16 workers. We restrict the sample to micro-firms with 1 to 6 workers to be consistent across industries. The ENAMIN allows a relatively precise construction of a wide variety of variables that represent basic firm and entrepreneur characteristics: profits, employment size, capital stocks, time in business, and engagement with a wide variety of societal institutions, including those for which treatment effects are estimated in this paper. In addition, we are able to construct, from the ENEU, several variables representing personal characteristics of the entrepreneur and

\footnotetext{
${ }^{8}$ See Heckman and Navarro-Lozano (2004) for a review of the different assumptions needed for each estimation procedure and recent development in control function semiparametric approaches.
} 
his/her household. These include the size of the household, and the entrepreneur's gender, age, level of schooling and position in the household (i.e. head or not).

The treatments are all captured as indicator (dummy) variables. The first is the receipt of at least one loan at some undetermined date after the business was established (New Credit). Since the ENAMIN provides information about the source of the corresponding loans, we are able to break this out into the receipt of loans from formal credit providers, namely banks or non-bank financial institutions (Formal Credit), and loans from informal sources, including family, friends, clients and suppliers (Informal Credit). Our second treatment is the receipt of some type of training during the year preceding the survey (Training) by either the owner of the firm or any of its workers. The third is the payment of at least some taxes as one of the regular expenditures made by the micro-firm (Taxes). Finally, our last treatment is membership in either the union or business association related to the firm's activity or sector (Guild).

As measures of firm performance we work primarily with "profits” as reported in the ENAMIN. This is calculated as revenues minus declared costs not including owner's labor and is perhaps better seen as a measure of income. In fact, as a robustness check, we also use the net income from self-employment reported by the owner of the firms when interviewed in the ENEU. In logs, the correlation of the two variables is 0.59 . We construct the variables measuring firm growth and survival, by exploiting the panel nature of the ENEU. The survey follows the owners of the firms covered by the ENAMIN for four quarters after the initial interview so we can calculate the log difference between initial and final income over a period of one year as a measure of growth. Survival is captured by a dummy variable indicating whether individuals that initially reported being self-employed (with the detailed firm characteristics covered in the ENAMIN) were still self employed a year later or rather transitioned to being salaried workers, unemployed or out of the labor market. Since the nature of the rotating panel implies that only $20 \%$ of the sample linked to the ENAMIN can be observed a year later, the samples in which we explore dynamic outcomes are reduced to about one-fifth of the original ENAMIN sample.

The variables employed in the paper are described in Appendix I with summary statistics presented in Table 1. Within the group of micro-firms on which we focus those with at most 6 workers - the average number of workers (besides the owner) is 0.6 , and two-thirds of the firms are owner-only. However, despite their small size the sampled 
micro-firms have been in business for 8 years on average, and 50\% are more than 5 years old. Average monthly profits are about US\$ 360, in prices of late 1997, with the median entrepreneur earning US\$205 per month. ${ }^{9}$ The median enterprise has a capital stock of about US\$600 and generates an income of US\$450.

As for personal and household characteristics, the average Mexican microentrepreneur in our sample is 42 years old and lives in a household with 4 other individuals. Almost 70\% are males, $83 \%$ of which are heads of household, compared to only $28 \%$ of female entrepreneurs that are household heads. Almost half of the microfirm owners in the sample have at most some primary education and only $15 \%$ have attended college.

With regard to the variables for which we estimate treatment effects, only $4 \%$ report having received a loan from financial institutions, and 7\% percent have borrowed from informal sources. A similarly low proportion of micro-firm owners (6\%) reports having received training themselves or offered it to their workers during the previous year and $17 \%$ belong to some type of union or business association. As mentioned before, the high degree of informality of the sector is illustrated by the fact that almost $70 \%$ of the sampled firms report not paying taxes on a regular basis.

\section{Results}

\section{IV.1. Propensity scores estimates}

Tables 2a-c present the standard probit models used to generate the propensity score for the six treatments analyzed: New Credit, Formal Credit, Informal Credit, Training, Taxes and Guild. The marginal effect on the probability of participating in a treatment is reported. As discussed earlier, we divide the conditioning variables $X$ into three sets: individual specific variables unlikely to be affected by the treatment, $H$; variables specific to the firm that may be important in explaining the treatment, but which may also be affected by it, $Z$; and finally the full set including other treatment variables, $F$. Each new set of variables progressively reduces the influence of omitted firm variables on the predicted likelihood of treatment. This makes the validity of the CIA more likely, but also potentially closes off some legitimate channels of influence.

\footnotetext{
${ }^{9}$ Similar values are obtained using the information reported as total net income from self-employment in the ENEU: that variable has an average of US\$325 and US\$219.
} 
Though the estimation of $P(X)$ is not the end of the analysis in itself and we do not examine it exhaustively, a few results merit noting. To begin, using the smallest conditioning set $H$, table 2a suggests that individual entrepreneur characteristics are significantly related to treatment, a perhaps unsurprising result given the small size of the firms. ${ }^{10}$ Older workers are more likely to engage in most institutions, as are the more educated. The exception here is that more educated workers are not especially more likely to have received informal credit than entrepreneurs with only primary education. ${ }^{11}$ Credit is more likely for entrepreneurs that are household heads and have larger households, while female micro-entrepreneurs are less likely to engage in all except training (perhaps because of the existence of government-sponsored training programs).

When we add variables specific to the firm, table $2 \mathrm{~b}$ shows that the importance of some individual characteristics falls significantly, suggesting that $H$ and $Z$ cannot be treated as orthogonal. First, the coefficient on the age of the entrepreneur and its significance both fall, possibly due to the inclusion of the time in business variable which is strongly significant in all treatments except training. The two size variables, capital stock and number of workers, enter positively and significantly in virtually all cases. Overall, this is consistent with Levenson and Maloney's formulation of formality, broadly conceived as participation across a variety of societal institutions, as a normal factor of production for firms operating in a Jovanovic (1982) type environment of noisy selection. In particular, larger and older firms could have a higher demand for the services provided by civil society institutions because they face a lower probability of failing, and a greater capacity for amortizing the fixed costs involved in participation (e.g. the cost of revealing their existence to tax authorities, membership fees, formal accounting procedures, etc.).

More specifically, both time in business and size may capture both greater credit worthiness and the availability of collateral, and hence access to credit. In terms of training, evidence from the US (Lynch and Black, 1995) shows that employers who had invested more in physical capital are more likely to have invested in workers’ instruction.

\footnotetext{
${ }^{10}$ For instance, as Berkowitz and White (2002) note for the US, debts are personal liabilities of the firm's owner, so that lending to a firm is legally equivalent to lending to its owner.

${ }^{11}$ This is consistent with many studies of credit markets in the US (see for instance Jappelli, 1990 and Blanchflower, Levine and Zimmerman, 2003) that find that age is highly significant for determining whether an individual is credit rationed. For training, many papers have studied individual decisions to be treated but fewer have looked at the firm (see for example Frazis, Gittleman and Joyce, 1998).
} 
Since participation in business associations is largely voluntary, the correlation with size and time in business suggests the normal good theory of participation. Again, being registered with taxes is more complicated, offering two observationally equivalent stories. On the one hand, bigger, more established firms need government services more. On the other, size and time in business are also likely to be correlated with the probability of detection by tax authorities under the evasion hypothesis of informality. Hence, we cannot empirically identify the relative importance of the "paying taxes to purchase services” and the "evasion” views by looking at these correlates alone but must wait for the impact of the treatment itself. In all cases, since in many theoretical models both size and time in business are actually driven by entrepreneurial ability (again, see Jovanovic, 1982 for an example), we are likely to be purging unmeasured entrepreneurial quality.

Table 2c adds the other treatments $(F)$. The results indicate a statistically significant positive correlation between all the dimensions of formality or participation in societal institutions hereby considered. The expansion of the conditioning set in the propensity score estimation therefore has the effect of capturing a possible general movement toward formalization and isolating the particular impact of each treatment. For instance, if the impact of registering with the tax authority is purely driven by the fact that this may be a precondition for accessing formal credit markets, then conditioning on the latter variable in the propensity score should reduce the measured impact of paying taxes on firm performance.

Probit estimates for the restricted sample that will be used for estimating treatment effects on growth and survival are not reported but they are available from the authors upon request. Overall the results are very similar to those in the full sample. Moreover, as could be expected given their high correlation with size and education, first period profits are positively correlated with the likelihood of receiving all treatments.

\section{IV.2. Matching and control function estimates.}

\section{Profit and income levels}

Tables 3, 4 and 5 report estimates of the treatment effects on profit levels, using OLS, matching and treatment regression techniques respectively. The naïve OLS estimates indicate that all the treatments have positive and significant effects on micro- 
firm profits, a result that is confirmed by the propensity score estimates. In both cases, the magnitude of the estimated effects is considerably sensitive to the set of regressors included in the propensity score model. This suggests that some caution needs to be taken when asserting the CIA, especially with narrow conditioning sets. In fact, in all cases, moving from the minimal to the complete conditioning set, reduces the impact of the treatments, in some cases dramatically: for example, the impact of new credit declines by a factor of almost four. How much of this is due to really eliminating the bias arising from violation of the CIA and how much to masking of the true effect by conditioning on Xs affected by the treatment is difficult to nail down. The matching estimates do allow for speculation on the direction of bias in the estimates of each treatment. When only the covariate set $H$ is used, we obtain the greatest ATT estimates, while their magnitude decreases as this set is enlarged (adding the sets $Z$ and $F$ ). As we mention earlier, the former should be considered as the upper bound and the latter the lower bound.

Appendix II analyzes the quality of matching, both looking at the standardized differences in the covariates and at the common support before and after matching. We are generally able to construct a distribution quite close to that of the treated group. As a result, estimates with and without imposing the common support restriction are very similar. We thus report only the estimates based on the whole support of the propensity score domain (restricted estimates are available upon request).

Table 5 presents the maximum likelihood control function estimates. The MLE estimates are less volatile than two-step procedures in the absence of exclusion restrictions although they impose further restrictions in the distribution of the error terms. In all the cases we compute robust standard errors. Further, simple tests for the structural break in $g_{0}$, $g_{1}$ suggests that the non-parametric approach to the impact of the treatments implicit in matching is more desirable. ${ }^{12}$

Taken together, the battery of estimation techniques and assumption sets generate striking commonalities that allow us to bracket the likely "true" value of the parameters. Although the magnitudes are generally somewhat lower, in virtually all cases, the estimates with the ENEU income variable are broadly consistent with those that emerge from the ENAMIN using the same estimation techniques. For this reason, we focus primarily on the results from the ENAMIN profit variable.

\footnotetext{
12 Two-step estimates and structural break tests are not reported here but they are available from the authors upon request.
} 
The impact of credit

The matching and OLS estimates suggest that firms treated with any kind of new credit have a profit level between $9 \%$ and 37\% , with the estimates falling dramatically moving from $\mathrm{P}(\mathrm{H})$ to $\mathrm{P}(\mathrm{H}, \mathrm{Z}, \mathrm{F})$ as would be predicted. The control function MLE estimates fall between these bounds (28\% and 36\%). A similar pattern is visible when we focus on the effect of receiving credit from formal sector sources, but the returns are substantially higher. Here, estimates range from $22 \%$ to $73 \%$ in the matching and OLS estimators and from $39 \%$ to $60 \%$ in the control function MLE approach. Access to informal credit, on the other hand, yields more modest results ranging from $3 \%$ to $23 \%$ in the matching and OLS estimates, with statistically non-significant effects when the full conditioning sets are used. With the control function MLE approach, however, the impact of informal credit on profits is significant with wider conditioning sets, and varies from $13 \%$ to $18 \%$.

Taken together, the results suggest that access to credit does improve performance and that formal credit has an impact perhaps two or three times that of informal credit. These estimates need to be taken with caution as the matching procedure cannot significantly reduce the post-matching bias in some Z- covariates (see Appendix II): the comparison group has on average less capital stock and employees than the treated group (25\% and $10 \%$ respectively for formal credit, $9 \%$ and $7 \%$ for informal credit). In consequence, our estimates are believed to be biased upward, and no further reduction in the bias can be done in this context. However, the fact that similar results are obtaining by the OLS extrapolation method contribute to the perception that our estimates are robust.

Paying taxes: bad luck or the price of useful government services?

The impact of paying taxes is large and significant with all three methods, ranging from $30 \%$ to $63 \%$ with OLS, $22 \%$ to $66 \%$ with propensity score matching and close to $60 \%$ in the control function MLE regressions. Strikingly not a single specification yields a negative coefficient that would be expected if being discovered by the government and being made to pay taxes were completely without benefit and constituted a pure tax. 
Overall, it would seem that, on average for those complying, paying taxes is not detrimental and something to be evaded, but actually improves firm performance. Again, under the evasion hypothesis, unlike the other treatments, there may be no bias if once controlling for the factors that would make a firm more visible, such as size or having been in business a long time, detection is more or less random or, perhaps negative if less clever entrepreneurs are detected more often. On the other hand, if registering to pay taxes buys services that increase income, the biases move in the same direction as those of the other treatments and the interpretation of the results needs to proceed similarly. In fact, the behavior of the estimates under different conditioning sets does seem to follow patterns similar to those of the other treatments, in particular, falling significantly as the conditioning set is expanded, with the only exception of the control function approach, where the argument for declining effects is in any case weaker, given that unobservables are expected to be controlled for even with the narrowest conditioning set. Thus, at minimum, formality in the straightforward sense of paying government taxes leads to a $20 \%$ increase in profits and, arguably, substantially more.

\section{Training and Business Associations}

OLS and matching estimates suggest that firms where the owner or some workers received training exhibit profits that are between $7 \%$ and 33\% higher than those of their peers. However, non-significant and even negative effects are obtained with control function models, potentially suggesting that unobserved entrepreneur characteristics could be driving the positive treatment effects derived with the other estimation methods. Moreover, the Appendix II shows that some post-matching bias in the Z-covariate set persists, revealing that training may be an exclusive attribute of large firms.

Finally, participation in a business association or guild has an impact of between $9 \%$ and $35 \%$ with OLS and matching methods, and an overlapping range of $7 \%$ to $22 \%$ with the control function. The lower bound across all techniques is around $10 \%$. 


\section{Income Growth}

The ability to link the ENAMIN to the ENEU means that we can create a panel where profits are observed at two points in time, and extensive firm and personal entrepreneur characteristics that would determine selection into treatment are available for the initial period. While the data is not structured to permit the use of a difference in differences matching approach that would clear out any unobserved characteristics that could violate the CIA, the possibility of controlling for initial profits provides some additional defense for the CIA.

Table 6 reports unconditional average income growth by treatment status. It clearly appears that without controlling by any enterprise or personal characteristics nontreated firms exhibit higher - although still negative, on average - rates of income growth. Our OLS, matching and control function estimates (tables 7 through 9) reduce this gap but do not reverse its sign. Moreover, with both OLS and matching, receiving credit - particularly if from informal sources - is significantly related to lower rates of income growth. The negative results are strongest with the Kernel matching but they are weakly echoed by the nearest neighbor matching estimates. These estimated negative treatment effects on growth could suggest that the treatment effects on the first period income move firms toward their steady state sizes with attendant reduction in growth rates as they converge. Alternatively, as matching is done on after-treatment initial levels of profits, one could argue that the worse performing treated are matched to the best nontreated, thus downwardly biasing the estimated treatment effects.

\section{Survival}

Table 10 shows the raw survival likelihood by treatment status: on average treated individuals show a $10 \%$ higher probability of survival. It thus appears that despite the lack of positive effect of the treatments on growth, they do increase the likelihood of micro-firm survival. Since control function techniques are not applicable in this context, 
we use propensity score matching estimates to check whether these differences are driven by the factors that determine selection into treatment. ${ }^{13}$

Although the effects become non-significant when other treatments are controlled for, both matching techniques suggest that access to credit is associated with higher survival probabilities (table 11). When using the Kernel approach these positive effects are also significant for loans received from either formal or informal sources, with larger magnitudes obtained in the former case. Moreover, while access to training and guild membership appear unrelated to firm survival, we find that firms that pay taxes are significantly more likely to stay in business, a result that is robust to changes in estimation methods and in the set of conditioning variables. Concerns about reverse causality cannot be completely ruled out as firms which foresee a bleaker future than what their fundamental and observable characteristics would lead to predict would have no incentive to comply with government regulations - including paying taxes. However, another possible interpretation is that credit and registering with the government provide firms with means for insuring themselves against negative shocks - e.g. ex-ante by diversifying their types of customers or ex-post by borrowing in bad times - thus increasing their odds of surviving them.

\section{Conclusion}

This paper has employed two different techniques to explore the impact of credit, training, tax payments and participation in business guilds on firm profits, growth and survival likelihood. To deal with the selection biases that are likely to affect naïve estimates of those treatment effects, we employ both propensity score matching and control function estimation methods, and take several different approaches to robustness testing.

In the end, the results of the two techniques are reasonably compatible with each other. We find positive impacts of all treatments on the profit levels of micro-firms, even in the cases where the use of wide conditioning sets may lead to underestimating true treatment effects. This suggests that even if best performing firms may be selected into

\footnotetext{
${ }^{13}$ See also Fajnzylber et al. (2005), which studies the determinants of micro-firm survival using probit models.
} 
participating in an increasing array of societal institutions, this participation does feed back into further improvements of firm performance.

We also find that at least access to credit and straightforwardly defined formality - the fact of paying government taxes - are significantly related to an increase in the likelihood of firm survival, a result that we interpret as reflecting increased access to better ex-ante and ex-post risk coping mechanisms. Finally, somewhat surprisingly, we find negative - although, except in the case of credit, non-significant - treatment effects on growth, a result that is consistent with treated firms being closer to their optimal or steady state sizes. 


\section{Appendix I: Variable description}

ENEU variables :

- Age: entrepreneur age.Age2: square of Age.

- Education: dummy for maximum education level reached. Prim: primary, Sec: secondary, High: more than secondary education. Base group: no education.

- Female: dummy for women.

- Married: dummy for married individuals.

- Npers: number of individuals in the household.

- Head: dummy variable for head of household.

- Real Income (Y): real monthly income from main job.

- Real Income Annual Growth (R): ln Real Wage ( $\left(t^{\prime}\right)$ - ln Real Wage ( $\left.t\right)$.

- Survival (S): dummy for entrepreneurs who were interviewed in the ENAMIN and declare to be self-employed/owners next year.

ENAMIN variables:

- Real Profits (Y): declared profits.

- Capital Stock: sum of the replacement cost of all owned or borrowed physical capital and the market price of all firm inventories.

- Number of Workers: number of paid and non-paid workers including owner.

- Credit: dummy for firms that got credit after the business started.

- Time in Business: years since owner began the activity or became head of the business.

- Credit: dummy for firms that obtained credit after start-up.

- Formal Credit: dummy if the credit was obtained from banks, savings accounts or lending institutions.

- Informal Credit: dummy if the credit was obtained from friends, relatives, clients, providers or particular lenders.

- Training: dummy for firms where the owner or any of the employees attended a training course the year before the ENAMIN was done.

- Taxes: dummy for firms that declared paying taxes either at the local or the federal level.

- Guild: dummy for firms affiliated to a guild. 


\section{- Appendix II: Tests for the Quality of Matching}

First we plot in figures AII-1 and AII-2 the propensity score kernel density estimates by treatment category. In the former case we use only $H$ for estimating the propensity score, while in the latter we use $(H, Z)$. Note that for Formal Credit and Training the non-treated distribution is collapsed around zero, meaning that our estimates are particularly successful in estimating non-participation, which could to some extent bias our estimates because of non-overlapping support. For Taxes, we also have strong predictive power when including the firm specific variables, but there exists a sufficient overlapping region.

Whether this constitutes a problem for matching can be informed by comparing the post-matching bias of certain covariates of the treated and the matched non-treated. Table AII-1 presents the post matching standardized bias (in percentage) of the selected covariates in all the matching estimations used through the paper. Most treatments show customary levels of matching quality for human capital and firm variables with the deviations falling well within $10 \%$ of one standard deviation (10.0). Formal Credit and Training are the treatments that show a higher bias, which means that it was difficult to find similar individuals to the treated ones. Note that larger deviations in capital stock, workers and time in business variables appear in the first panel. Figures AII-3 and AII-4 plot the treated and the matched (re-weighted) non-treated densities, which show that propensity score matching does a relatively good job. As a final check for the nonoverlapping common support problem we also used matching estimators with trimming, imposing a common support for treated and non-treated on the propensity score domain. The estimated treatment effects are very similar to those reported through the text. These estimates are available from the authors upon request.

We also present some descriptive statistics on post-matching bias for the restricted sample used for growth and survival analysis (table AII-2). 
Table AII-1 - Post-matching standardized bias of selected covariates (in \%)

\begin{tabular}{l|cccccc}
\hline \hline (complete sample) & $\begin{array}{c}\text { New } \\
\text { Credit }\end{array}$ & $\begin{array}{c}\text { Formal } \\
\text { Credit }\end{array}$ & $\begin{array}{c}\text { Informal } \\
\text { Credit }\end{array}$ & Training & Taxes & Guild \\
\hline Matching using $H$ & & & & & & \\
In Capital Stock* & 51.0 & 80.4 & 39.9 & 44.2 & 89.4 & 39.4 \\
In Workers* & 51.4 & 72.6 & 38.6 & 31.4 & 62.7 & 32.9 \\
Time in Business* & 14.5 & 24.6 & 6.2 & -0.4 & 18.8 & 21.7 \\
Age & -0.2 & -1.6 & 0.0 & -7.8 & 0.5 & -0.4 \\
Prim & -1.3 & -9.5 & -1.8 & -10.0 & -1.1 & 2.5 \\
Sec & 0.2 & 3.5 & 2.3 & 6.3 & -3.8 & 0.1 \\
High & 1.3 & 10.0 & 0.4 & 5.6 & 4.4 & -2.7 \\
\hline Matching using (H,Z) & & & & & & \\
In Capital Stock & 8.0 & 25.5 & 9.3 & 10.4 & 3.9 & 3.0 \\
In Workers & 2.2 & 10.3 & 7.3 & 0.2 & -0.1 & -2.8 \\
Time in Business & 1.5 & 0.8 & 0.7 & -0.6 & 3.7 & -1.6 \\
Age & 0.8 & -3.4 & 0.4 & -6.7 & 2.7 & -0.8 \\
Prim & 0.2 & -3.3 & -1.1 & -9.0 & 2.8 & 2.5 \\
Sec & 0.8 & 2.7 & 1.9 & 4.9 & -2.0 & 0.6 \\
High & -0.6 & 3.2 & -0.2 & 6.1 & -2.0 & -3.0 \\
\hline Matching using (H,Z, F) & & & & & & \\
In Capital Stock & 7.6 & 24.8 & 8.9 & 8.7 & 3.4 & 2.4 \\
In Workers & 2.7 & 10.5 & 7.3 & -1.5 & 0.6 & -3.0 \\
Time in Business & 1.5 & 1.0 & 0.6 & -0.6 & 3.4 & -1.8 \\
Age & 0.8 & -3.1 & 0.5 & -7.0 & 2.6 & -0.7 \\
Prim & 0.1 & -3.4 & -1.1 & -8.8 & 2.2 & -8.5 \\
Sec & 1.0 & 3.1 & 1.9 & 5.6 & -2.1 & 0.7 \\
High & -0.9 & 2.7 & -0.3 & 5.1 & -1.1 & -3.2 \\
\hline \hline
\end{tabular}

Notes: * not used for matching. All the results correspond to Nearest Neighbor matching procedure. 
Table AII-2- Post-matching standardized bias of selected covariates (in \%)

\begin{tabular}{l|cccccc}
\hline \hline & New Credit & $\begin{array}{c}\text { Formal } \\
\text { Credit }\end{array}$ & $\begin{array}{c}\text { Informal } \\
\text { Credit }\end{array}$ & Training & Taxes & Guild \\
\hline Matching using $(H, Z, Y)$ & & & & & & \\
(small sample - survivors & & & & & & \\
only) & & & & & & \\
In Initial Income & 2.3 & 14.4 & 10.9 & 2.1 & 3.5 & 1.8 \\
In Capital Stock & 0.5 & 25.2 & 6.8 & 9.9 & 3.0 & 4.7 \\
In Workers & 2.4 & 7.0 & 7.7 & 2.1 & 2.6 & 0.3 \\
Time in Business & -4.2 & 1.7 & 3.6 & -2.2 & 4.1 & -5.3 \\
Age & -2.7 & -1.2 & 6.4 & -7.5 & 4.5 & 8.5 \\
Prim & -2.1 & -2.2 & -1.7 & -9.9 & 0.2 & 2.1 \\
Sec & 1.4 & 1.9 & 0.0 & 6.9 & -0.4 & -3.0 \\
High & 1.6 & 3.0 & 2.3 & 4.4 & 0.0 & 0.0 \\
\hline Matching using $(H, Z, Y)$ & & & & & & \\
(small sample - all) & & & & & & \\
In Initial Income & 3.0 & 11.8 & 2.0 & 7.1 & -0.8 & -1.4 \\
In Capital Stock & 2.5 & 23.0 & 0.7 & 9.8 & 3.2 & 4.6 \\
In Workers & 4.9 & 7.8 & 4.6 & 3.2 & 2.0 & 0.9 \\
Time in Business & -0.6 & 4.6 & -1.2 & 2.1 & 3.9 & -5.9 \\
Age & -0.1 & 0.9 & 0.2 & -3.9 & 3.6 & -1.7 \\
Prim & -0.9 & -5.3 & 0.0 & -7.6 & 0.9 & 1.6 \\
Sec & -0.6 & 4.7 & -1.1 & 0.4 & -0.8 & -1.5 \\
High & 2.4 & 2.0 & 2.6 & 9.2 & -0.7 & -1.0 \\
\hline \hline
\end{tabular}

Notes: * not used for matching. All the results correspond to Nearest Neighbor matching procedure. 
Figure AII-1
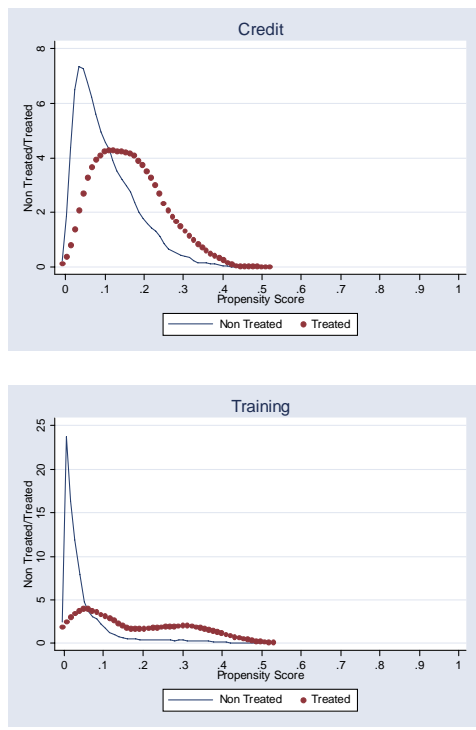

\section{Figure AII-2}

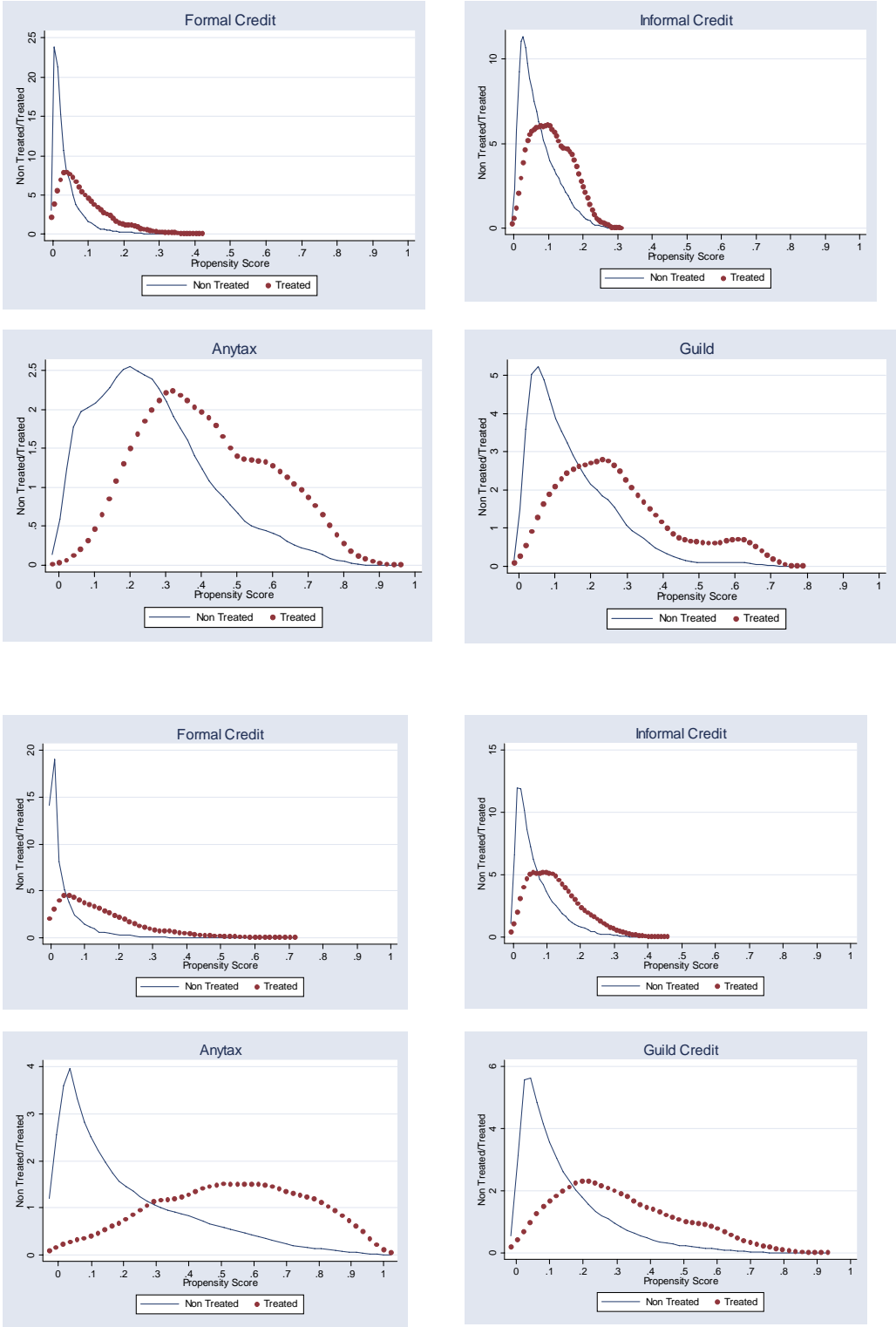
Figure AII-3
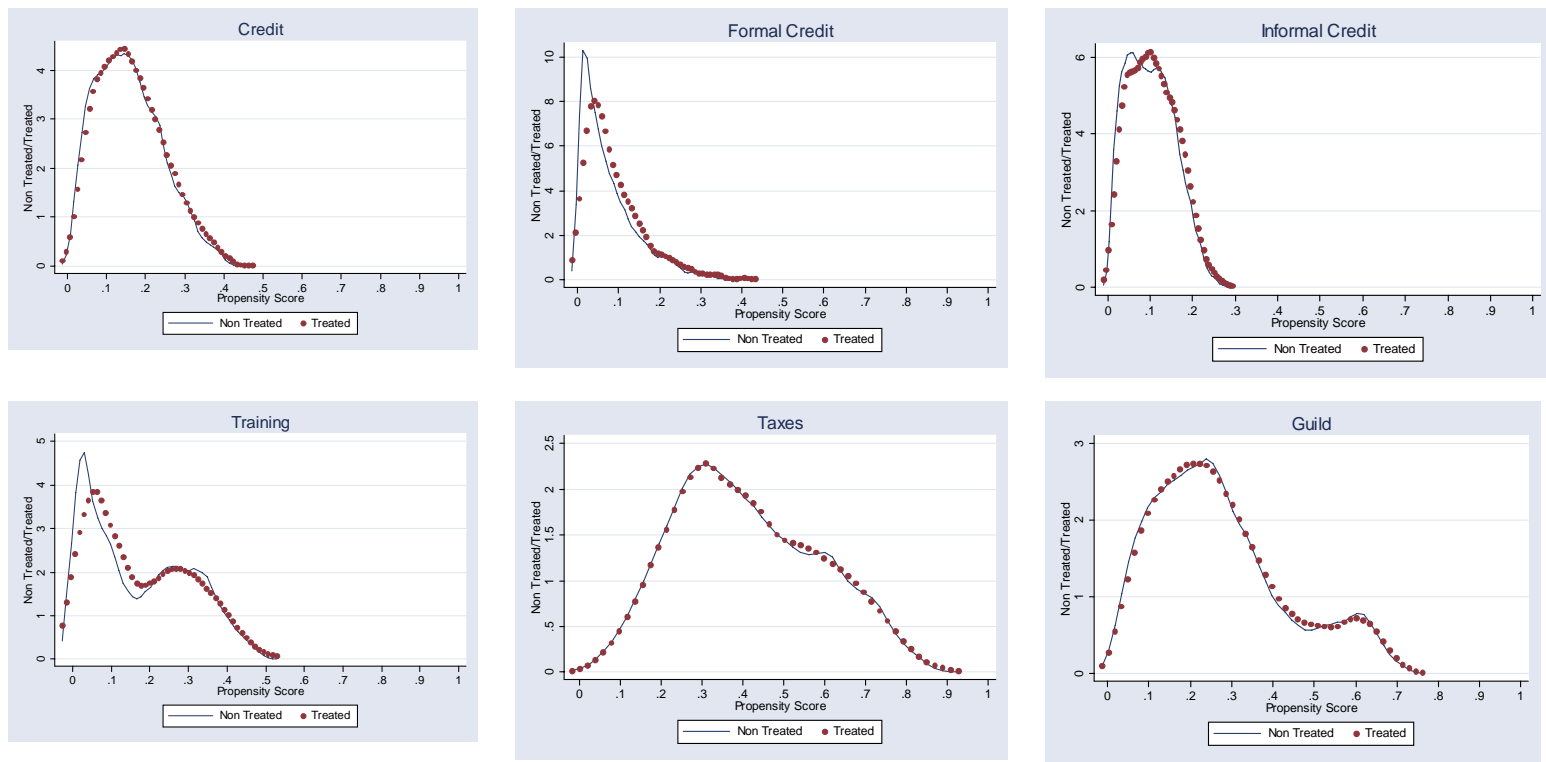

Figure AII-4
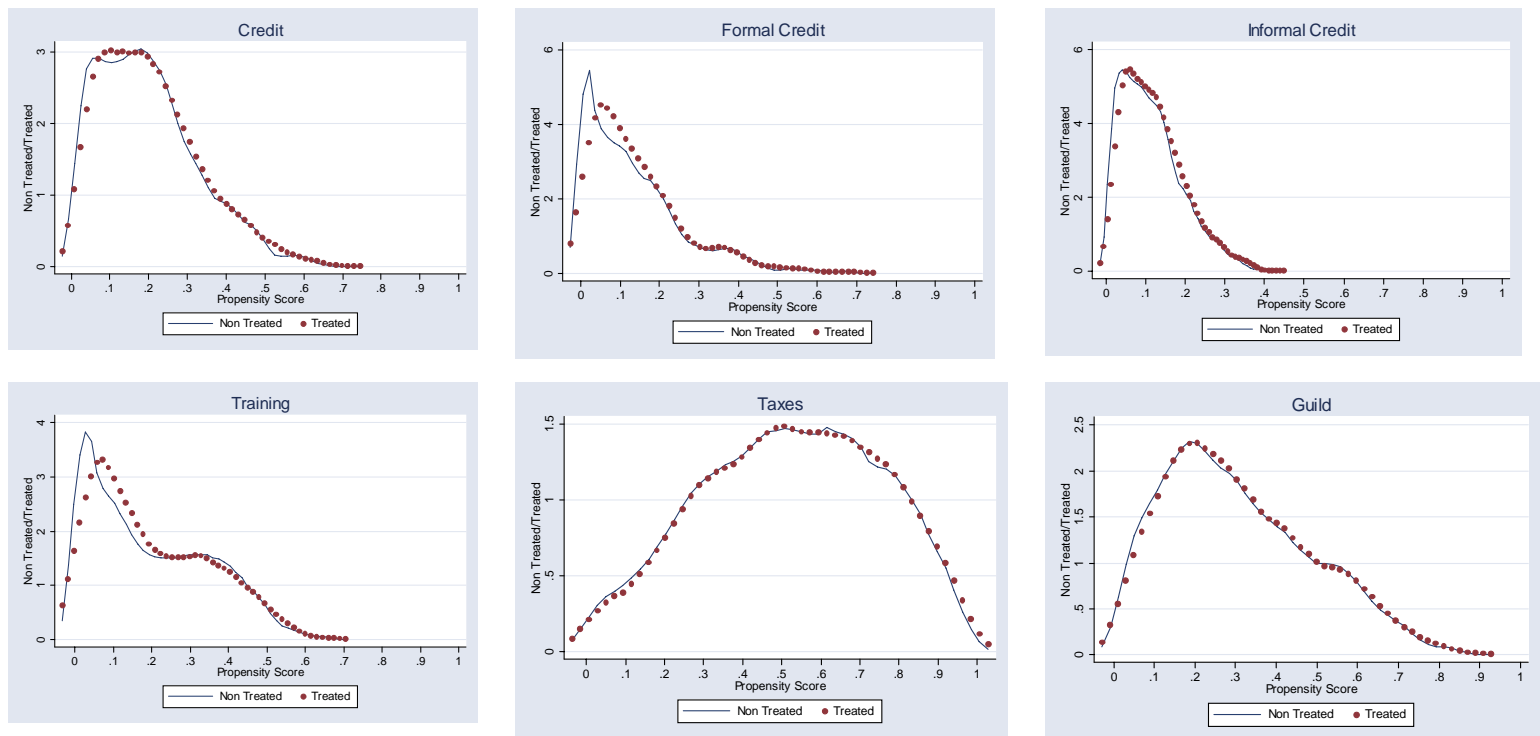


\section{References}

Alesina, A., and La Ferrara, E. (2000ª). "The Determinants of Trust." NBER Working Paper N.7621.

Angrist, J.D. and Hahn, J. (1999). "When to Control for Covariates? Panel-Asymptotic Results for Estimates of Treatment Effects”, NBER Technical Working Paper N.241.

Berkowitz, J. and White, M. (2002). “Bankruptcy and Small Firms’ Access to Credit”, NBER Working Paper N.9010.

Blanchflower, D.G., Levine, P.B., and Zimmerman D.J. (2003). “Discrimination in the Small-Business Credit Market”, The Review of Economic and Statistics 85(4):930-943.

Coleman, J.S. (1990). Foundations of Social Theory. Cambridge, Massachusetts and London, England: Harvard University Press.

de Soto, H. (1989). The Other Path: The Invisible Revolution in the Third World, New York: Harper and Row.

Dehejia, R.H. and Wahba, S. (1999). “Casual Effects in Nonexperimental Studies: Reevaluating the Evaluation of Training Programs”, Journal of the American Statistical Association, 94:1053-62. (2002). “Propensity Score-Matching Methods for Nonexperimental Causal Studies”, The Review of Economics and Statistics, 84:151-61.

Fajnzylber, P., Maloney, W. and Montes Rojas, G. (2005). “Micro-Firm Dynamics in Less Developed Countries: How Similar are they to those in the Industrialized World? Evidence from Mexico”, mimeo.

Frazis, H. , Gittleman, M. and Joyce, M. (1998). "Determinants of Training: An Analysis using Both Employer and Employee Characteristics”, BLS Research Papers.

Galasso, E., Ravallion,M. and Salvia,A. (2001). “Assisting the Transition from Workfare to Work: A Randomized Experiment”, Mimeo.

Glaeser, E.L., Laibson, D., and Sacerdote,B. (2000). "The Economic Approach to Social Capital.", NBER Working Paper N.7728.

Harris, J.R. and Todaro, M.R. (1970). "Migration, unemployment and development: a two-sector analysis”, American Economic Review, 60, 126-42. 
Heckman, J.J. (1976). “Sample Selection Bias as a Specification Error”, Econometrica, .47: $153-62$.

Heckman, J.J., Ichimura, H., Smith, J. and Todd, P. (1998). "Characterizing Selection Bias Using Experimental Data”, Econometrica, 66:1017-98. Heckman, J.J., Ichimura, H. and Todd, P. (1997). “Matching as an Econometric Evaluation Estimator: Evidence from Evaluating a Job Training Programs”, The Review of Economic Studies, v.64(4):605-54. (1998). "Matching as an Econometric Evaluation Estimator”, The Review of Economic Studies, v65(2):261-94.

Heckman, J.J., LaLonde, R.J. and Smith, J.A. (1999). “The Economics and Econometrics of Active Labor Market Programs”, in Orley Ashenfelter and David Card (eds.) , Handbook of Labor Economics, Volume II , Elsevier Science Pub. Co.

Heckman, J.J. and Navarro-Lozano,S. (2004). “Using Matching, Instrumental Variables and Control Functions to Estimate Economic Choice Models”, The Review of Economic and Statistics 86: 30-57.

Heckman, J.J. and Robb, R. (1985). “Alternative Methods For Evaluating The Impact of Interventiuons”, in J.Heckman and B. Singer (eds.), Longitudinal Analysis of Labor Market Data, Cambridge University Press.

Heckman, J.J., Tobias, J.L. and Vytlacil, E. (2000). “Simple Estimators for Treatment Parameters in a Latent Variables Framework with an Application to Estimating the Returns to Schooling”, NBER Working Paper 7950.

Imbens, G.W. (1999). “The Role of Propensity Score in Estimating Dose-Response Functions”, NBER Technical Working Paper N.237.

Imbens, G.W. (2004). "Nonparametric Estimation of Average Treatment Effects Under Exogeneity: A Review”, The Review of Economics and Statistics 86: 4-29.

Jappelli, T. (1990). “Who is Credit Constrained in the U.S. Economy?”, The Quarterly Journal of Economics, 105: 219-34.

Jalan, J. and Ravallion, M. (2003) "Estimating the Benefit Incidence of an Anti-Poverty Program by Propensity-Score Matching”, Journal of Business and Economic Statistics, v.21:19-30.

Jovanovic, B. (1982). “Selection and Evolution of Industry,” Econometrica, v.50(3): 64970. 
Lechner, M. (2002). “Program Heterogeneity and Propensity Score Matching: An Application to the Evaluation of Active Labor Market Policies”, The Review of Economics and Statistics, v82:205-220.

Levenson, A.R. and Maloney, W.F. (1996). 'Modeling the Informal Sector: Theory and Empirical Evidence from Mexico," University of Illinois and the Milken Institute.

Loayza, N.V. (1996). "The Economics of the Informal Sector: A Simple Model and Some Empirical Evidence from Latin America,” Carnegie-Rochester Conference Series on Public Policy 45:129-162.

Lucas, R.E., Jr. (1978). “On the Size Distribution of Business Firms”, Bell Journal of Economics 9(2), 508-23.

Lynch, L.M. and Black, S.E. (1995). "Beyond the Incidence of Training: Evidence from a National Employers Survey”, NBER Working Paper N.5231

Manski, C.F. (1990). “Nonparametric Bounds on Treatment Effects”, The American Economic Review, v.80(2):319-23.

Newman, J., Pradhan, M., Rawlings, L.B. Ridder, G., Coa, R. and Evia, J.L. (2002). “An Impact of Education, Health, and Water Supply Investments by the Bolivian Social Investment Fund”, The World Bank Economic Review, 16: 241-74.

Portes, A. and Landolt, P. (2000). "Social Capital: Promise and Pitfalls of Its Role in Development,” Journal of Latin American Studies, 32: 529-547.

Rosenbaum, P.R. and Rubin, D.B. (1983). “The Central Role of the Propensity Score in Observational Studies for Causal Effects”, Biometrika, 70:41-55.

(1983b). “Assessing Sensitivity to an Unobserved Binary Covariate in an Observational study with Binary Outcome”, Journal of the Royal Statistical Society, Series B (Methodological), 45: 212-8.

Smith, J.A. and Todd, P.E. (2001). “ Reconciling Conflicting Evidence on the Performance of Propensity-Score Matching Methods,” The American Economic Review, 91: 112-118.

Smith, J.A. and Todd, P.E. (2003). “Does Matching Overcome Lalonde’s Critique of Nonexperimental Estimators?," University of Maryland.

Stiglitz, J.E. (2000). "Formal and Informal Institutions.", in P. Dasgupta and I.

Serageldin, editors, Social Capital: A Multifaceted Perspective. Washington, DC: The World Bank. 
Tybout, J.R. (2000) "Manufacturing Firms in Developing Countries: How Well Do They Do, and Why?," Journal of Economic Literature 38(1): 11-44. 
Table 1 - Summary statistics

\begin{tabular}{lccccc}
\hline \hline \multicolumn{6}{c}{ ENAMIN-ENEU (Complete sample) } \\
\hline Var. & Obs. & Mean & Std.Dev. & Min. & Max. \\
\hline log Real Income* & 31867 & 7.42 & 0.95 & 2.62 & 12.59 \\
log Real Profits & 32077 & 7.42 & 1.20 & -0.11 & 13.27 \\
New Credit & 35044 & 0.11 & 0.31 & 0.00 & 1.00 \\
Formal Credit & 35044 & 0.04 & 0.20 & 0.00 & 1.00 \\
Informal Credit & 35044 & 0.07 & 0.26 & 0.00 & 1.00 \\
Training & 35044 & 0.06 & 0.24 & 0.00 & 1.00 \\
Taxes & 35044 & 0.31 & 0.46 & 0.00 & 1.00 \\
Guild & 35044 & 0.17 & 0.38 & 0.00 & 1.00 \\
log Capital Stock & 35044 & 7.97 & 3.39 & -0.11 & 16.22 \\
log Workers & 35044 & 0.33 & 0.48 & 0.00 & 1.79 \\
Time in Business & 35037 & 8.21 & 9.19 & 0.17 & 51.00 \\
Female & 35044 & 0.30 & 0.46 & 0.00 & 1.00 \\
Head* & 35044 & 0.67 & 0.47 & 0.00 & 1.00 \\
Npers* & 35044 & 4.81 & 2.22 & 1.00 & 23.00 \\
Married & 35044 & 0.74 & 0.44 & 0.00 & 1.00 \\
Age & 35044 & 42.13 & 13.55 & 12.00 & 97.00 \\
Age2 & 35044 & 1958.59 & 1253.38 & 144.00 & 9409.00 \\
Prim & 35044 & 0.46 & 0.50 & 0.00 & 1.00 \\
Sec & 35044 & 0.33 & 0.47 & 0.00 & 1.00 \\
High & 35044 & 0.16 & 0.36 & 0.00 & 1.00 \\
\hline \hline ENEU & & & & &
\end{tabular}

* ENEU 
Table 1 (cont.) - Summary statistics

\begin{tabular}{lccccc}
\hline \hline \multicolumn{5}{c}{ ENAMIN-ENEU (Small sample) } \\
\hline Var. & Obs. & Mean & Std.Dev. & Min. & Max. \\
\hline Dif. log Real Income* & 4480 & -0.06 & 0.79 & -4.11 & 4.06 \\
log Real Income (all)* & 5392 & 7.44 & 0.97 & 3.04 & 12.59 \\
log Real Profits (all) & 5418 & 7.44 & 1.19 & -0.11 & 11.92 \\
log Real Income (surv.)* & 3993 & 7.54 & 0.93 & 3.38 & 12.59 \\
log Real Profits (surv.) & 4043 & 7.54 & 1.17 & -0.11 & 11.51 \\
New Credit & 5925 & 0.16 & 0.37 & 0.00 & 1.00 \\
Formal Credit & 5925 & 0.04 & 0.20 & 0.00 & 1.00 \\
Informal Credit & 5925 & 0.13 & 0.33 & 0.00 & 1.00 \\
Training & 5925 & 0.06 & 0.24 & 0.00 & 1.00 \\
Taxes & 5925 & 0.31 & 0.46 & 0.00 & 1.00 \\
Guild & 5925 & 0.17 & 0.37 & 0.00 & 1.00 \\
log Capital Stock & 5925 & 8.03 & 3.38 & 0.00 & 16.00 \\
log Workers & 5925 & 0.34 & 0.49 & 0.00 & 1.79 \\
Time in Business & 5923 & 8.30 & 9.41 & 0.17 & 51.00 \\
Female & 5925 & 0.30 & 0.46 & 0.00 & 1.00 \\
Head* & 5925 & 0.69 & 0.46 & 0.00 & 1.00 \\
Npers* & 5925 & 4.81 & 2.20 & 1.00 & 17.00 \\
Married & 5925 & 0.75 & 0.43 & 0.00 & 1.00 \\
Age & 5925 & 42.73 & 13.54 & 12.00 & 90.00 \\
age2 & 5925 & 2008.75 & 1263.41 & 144.00 & 8100.00 \\
Prim & 5925 & 0.47 & 0.50 & 0.00 & 1.00 \\
Sec & 5925 & 0.32 & 0.47 & 0.00 & 1.00 \\
High & 5925 & 0.15 & 0.36 & 0.00 & 1.00 \\
Survival & 5925 & 0.74 & 0.44 & 0.00 & 1.00 \\
\hline \hline ENEU. (surv.) survivor 014. & & & & \\
\end{tabular}

* ENEU. (surv.): survivors only. 
Table 2a - Probit estimates

Treatment

\begin{tabular}{l|rrrrrr}
\hline & New Credit & $\begin{array}{r}\text { Formal } \\
\text { Credit }\end{array}$ & $\begin{array}{c}\text { Informal } \\
\text { Credit }\end{array}$ & Training & Taxes & Guild \\
\hline In Capital Stock & & & & & & \\
In Workers & & & & & & \\
Time in Business & & & & & & \\
& & & & & & \\
Female & & & & & & \\
Head & & & & & & \\
& & & & & & \\
Npers & -0.065 & -0.146 & -0.022 & 0.183 & -0.136 & -0.239 \\
& $-(2.30)^{*}$ & $-(3.36)^{* *}$ & $-(0.71)$ & $(5.14)^{* *}$ & $-(6.13)^{* *}$ & $-(9.27)^{* *}$ \\
Married & 0.138 & 0.118 & 0.12 & 0.029 & 0.081 & 0.064 \\
& $(4.91)^{* *}$ & $(2.77)^{* *}$ & $(3.87)^{* *}$ & $-(0.81)$ & $(3.69)^{* *}$ & $(2.54)^{*}$ \\
Age & 0.014 & 0.007 & 0.014 & -0.013 & -0.009 & 0.012 \\
& $(2.97)^{* *}$ & $(0.99)$ & $(2.75)^{* *}$ & $(1.95)$ & $(2.27)^{*}$ & $(2.82)^{* *}$ \\
Age2 & 0.051 & 0.11 & 0.01 & 0.001 & 0.14 & 0.017 \\
& $(2.08)^{*}$ & $(2.97)^{* *}$ & $(0.38)$ & $(0.03)$ & $(7.33)^{* *}$ & $(0.78)$ \\
Prim & 0.031 & 0.06 & 0.013 & 0.038 & 0.054 & 0.033 \\
& $(6.79)^{* *}$ & $(8.50)^{* *}$ & $(2.54)^{*}$ & $(5.81)^{* *}$ & $(15.45)^{* *}$ & $(8.36)^{* *}$ \\
Sec & 0.0000 & -0.0010 & 0.0000 & 0.0000 & 0.0000 & 0.0000 \\
& $(7.28)^{* *}$ & $-(7.61)^{* *}$ & $(3.82)^{* *}$ & $(6.32)^{* *}$ & $(12.92)^{* *}$ & $(7.43)^{* *}$ \\
& 0.141 & 0.118 & 0.128 & 0.079 & 0.228 & 0.099 \\
& $(3.89)^{* *}$ & $(2.18)^{*}$ & $(3.20)^{* *}$ & $(1.37)$ & $(8.08)^{* *}$ & $(3.14)^{* *}$ \\
& 0.355 & 0.48 & 0.221 & 0.632 & 0.611 & 0.202 \\
& $(9.32)^{* *}$ & $(8.50)^{* *}$ & $(5.25)^{* *}$ & $(10.76)^{* *}$ & $(20.37)^{* *}$ & $(5.98)^{* *}$ \\
& 0.597 & 0.893 & 0.264 & 1.097 & 1.135 & 0.379 \\
& $(13.24)^{* *}$ & $(13.97)^{* *}$ & $(5.17)^{* *}$ & $(16.89)^{* *}$ & $(31.35)^{* *}$ & $(9.38)^{* *}$ \\
& & & & & &
\end{tabular}

Formal Credit

Informal Credit

Training

Taxes

Guild

\begin{tabular}{lrrrrrr} 
Constant & -2.277 & -3.741 & -1.892 & -3.037 & -2.61 & -1.871 \\
& $-(19.14)^{* *}$ & $-(20.45)^{* *}$ & $-(14.47)^{* *}$ & $-(17.66)^{* *}$ & $-(27.58)^{* *}$ & $-(17.69)^{* *}$ \\
\hline Observations & 35044 & 35044 & 35044 & 35044 & 35044 & 35044 \\
\hline Pseudo R2 & 0.0870 & 0.1213 & 0.0757 & 0.1978 & 0.1307 & 0.1318 \\
Prob > Chi2 & 0.000 & 0.000 & 0.000 & 0.000 & 0.000 & 0.000 \\
\hline \hline
\end{tabular}

Notes: Estimation includes dummies by year, industry and state although they are not reported.

$\mathrm{z}$ values in (). * significant at $5 \%$; ** significant at $1 \%$ 
Table 2b - Probit estimates

\begin{tabular}{|c|c|c|c|c|c|c|}
\hline & \multicolumn{6}{|c|}{ Treatment } \\
\hline & New Credit & $\begin{array}{c}\text { Formal } \\
\text { Credit }\end{array}$ & $\begin{array}{c}\text { Informal } \\
\text { Credit }\end{array}$ & Training & Taxes & Guild \\
\hline In Capital Stock & $\begin{array}{r}0.079 \\
(19.49)^{* *}\end{array}$ & $\begin{array}{r}0.12 \\
(16.59)^{* *}\end{array}$ & $\begin{array}{r}0.056 \\
(12.75)^{* *}\end{array}$ & $\begin{array}{r}0.071 \\
(13.84)^{* *}\end{array}$ & $\begin{array}{r}0.198 \\
(54.65)^{* *}\end{array}$ & $\begin{array}{r}0.067 \\
(19.58)^{* *}\end{array}$ \\
\hline In Workers & $\begin{array}{r}0.418 \\
(20.63)^{* *}\end{array}$ & $\begin{array}{r}0.445 \\
(15.85)^{* *}\end{array}$ & $\begin{array}{r}0.283 \\
(12.37)^{* *}\end{array}$ & $\begin{array}{r}0.248 \\
(9.66)^{* *}\end{array}$ & $\begin{array}{r}0.483 \\
(27.26)^{* *}\end{array}$ & $\begin{array}{r}0.319 \\
(16.97)^{* *}\end{array}$ \\
\hline Time in Business & $\begin{array}{r}0.011 \\
(8.68)^{* *}\end{array}$ & $\begin{array}{r}0.018 \\
(9.98)^{* *}\end{array}$ & $\begin{array}{r}0.004 \\
(2.97)^{* *}\end{array}$ & $\begin{array}{l}-0.001 \\
-(0.42)\end{array}$ & $\begin{array}{r}0.012 \\
(11.78)^{* *}\end{array}$ & $\begin{array}{r}0.018 \\
(16.18)^{* *}\end{array}$ \\
\hline Female & $\begin{array}{r}0.049 \\
(1.64)\end{array}$ & $\begin{array}{l}-0.016 \\
-(0.33)\end{array}$ & $\begin{array}{l}0.055 \\
(1.69)\end{array}$ & $\begin{array}{r}0.287 \\
(7.72)^{* *}\end{array}$ & $\begin{array}{r}0.058 \\
(2.33)^{*}\end{array}$ & $\begin{array}{r}-0.151 \\
-(5.64)^{* *}\end{array}$ \\
\hline Head & $\begin{array}{r}0.109 \\
(3.70)^{* *}\end{array}$ & $\begin{array}{r}0.074 \\
(1.58)\end{array}$ & $\begin{array}{r}0.102 \\
(3.19)^{* *}\end{array}$ & $\begin{array}{c}0.012 \\
(0.33)\end{array}$ & $\begin{array}{r}0.038 \\
(1.55)\end{array}$ & $\begin{array}{l}0.029 \\
(1.10)\end{array}$ \\
\hline Npers & $\begin{array}{r}0.01 \\
(2.04)^{*}\end{array}$ & $\begin{array}{l}0.002 \\
(0.20)\end{array}$ & $\begin{array}{r}0.012 \\
(2.26)^{*}\end{array}$ & $\begin{array}{r}-0.014 \\
-(1.98)^{*}\end{array}$ & $\begin{array}{r}-0.015 \\
(3.56)^{* *}\end{array}$ & $\begin{array}{r}0.008 \\
(1.81)\end{array}$ \\
\hline Married & $\begin{array}{l}-0.018 \\
-(0.71)\end{array}$ & $\begin{array}{l}0.042 \\
(1.04)\end{array}$ & $\begin{array}{l}-0.039 \\
-(1.41)\end{array}$ & $\begin{array}{l}-0.048 \\
-(1.52)\end{array}$ & $\begin{array}{l}0.029 \\
(1.38)\end{array}$ & $\begin{array}{l}-0.039 \\
-(1.71)\end{array}$ \\
\hline Age & $\begin{array}{r}0.013 \\
(2.78)^{* *}\end{array}$ & $\begin{array}{r}0.046 \\
(5.96)^{* *}\end{array}$ & $\begin{array}{l}-0.001 \\
-(0.13)\end{array}$ & $\begin{array}{r}0.028 \\
(4.13)^{* *}\end{array}$ & $\begin{array}{r}0.031 \\
(8.08)^{* *}\end{array}$ & $\begin{array}{r}0.018 \\
(4.37)^{* *}\end{array}$ \\
\hline Age2 & $\begin{array}{r}0.0000 \\
(4.39)^{* *}\end{array}$ & $\begin{array}{c}-0.0010 \\
(6.22)^{* *}\end{array}$ & $\begin{array}{r}0.0000 \\
(1.64)\end{array}$ & $\begin{array}{r}0.0000 \\
(4.75)^{* *}\end{array}$ & $\begin{array}{r}0.0000 \\
(6.87)^{* *}\end{array}$ & $\begin{array}{r}0.0000 \\
(5.12)^{* *}\end{array}$ \\
\hline Prim & $\begin{array}{r}0.076 \\
(1.97)^{*}\end{array}$ & $\begin{array}{r}0.01 \\
(0.15)\end{array}$ & $\begin{array}{r}0.088 \\
(2.10)^{*}\end{array}$ & $\begin{array}{l}0.058 \\
(0.93)\end{array}$ & $\begin{array}{r}0.112 \\
(3.53)^{* *}\end{array}$ & $\begin{array}{l}0.031 \\
(0.94)\end{array}$ \\
\hline $\mathrm{Sec}$ & $\begin{array}{r}0.171 \\
(4.17)^{* *}\end{array}$ & $\begin{array}{r}0.233 \\
(3.60)^{* *}\end{array}$ & $\begin{array}{r}0.093 \\
(2.10)^{*}\end{array}$ & $\begin{array}{r}0.497 \\
(7.84)^{* *}\end{array}$ & $\begin{array}{r}0.294 \\
(8.65)^{* *}\end{array}$ & $\begin{array}{c}0.032 \\
(0.90)\end{array}$ \\
\hline $\begin{array}{l}\text { High } \\
\text { Formal Credit }\end{array}$ & $\begin{array}{r}0.252 \\
(5.18)^{* *}\end{array}$ & $\begin{array}{r}0.466 \\
(6.40)^{* *}\end{array}$ & $\begin{array}{c}0.017 \\
(0.31)\end{array}$ & $\begin{array}{r}0.845 \\
(12.05)^{* *}\end{array}$ & $\begin{array}{r}0.575 \\
(14.07)^{* *}\end{array}$ & $\begin{array}{r}0.086 \\
(2.00)^{*}\end{array}$ \\
\hline Informal Credit & & & & & & \\
\hline Training & & & & & & \\
\hline Taxes & & & & & & \\
\hline Guild & & & & & & \\
\hline Constant & $\begin{array}{r}-2.649 \\
-(21.03)^{* *}\end{array}$ & $\begin{array}{r}-4.633 \\
-(22.29)^{* *}\end{array}$ & $\begin{array}{r}-2.116 \\
-(15.65)^{* *}\end{array}$ & $\begin{array}{r}-3.484 \\
-(19.40)^{* *}\end{array}$ & $\begin{array}{r}-3.88 \\
-(36.04)^{* *}\end{array}$ & $\begin{array}{r}-2.144 \\
-(19.40)^{* *}\end{array}$ \\
\hline Observations & 35037 & 35037 & 35037 & 35037 & 35037 & 35037 \\
\hline Pseudo R2 & 0.1473 & 0.2170 & 0.1054 & 0.2279 & 0.2831 & 0.1749 \\
\hline Prob > Chi2 & 0.000 & 0.000 & 0.000 & 0.000 & 0.000 & 0.000 \\
\hline
\end{tabular}

Notes: Estimation includes dummies by year, industry and state although they are not reported.

$\mathrm{z}$ values in (). * significant at $5 \%$; ** significant at $1 \%$ 
Table 2c - Probit estimates

Treatment

\begin{tabular}{|c|c|c|c|c|c|c|}
\hline & New Credit & $\begin{array}{c}\text { Formal } \\
\text { Credit }\end{array}$ & $\begin{array}{c}\text { Informal } \\
\text { Credit }\end{array}$ & Training & Taxes & Guild \\
\hline \multirow[t]{2}{*}{ In Capital Stock } & 0.068 & 0.103 & 0.049 & 0.057 & 0.193 & 0.052 \\
\hline & $(15.96)^{* *}$ & $(13.91)^{* *}$ & $(10.68)^{* *}$ & $(10.62)^{* *}$ & $(52.77) * *$ & $(14.64)^{* *}$ \\
\hline \multirow[t]{2}{*}{ In Workers } & 0.375 & 0.398 & 0.254 & 0.175 & 0.454 & 0.258 \\
\hline & $(18.08) * *$ & $(13.87)^{* *}$ & $(10.89)^{* *}$ & $(6.56)^{* *}$ & $(25.24)^{* *}$ & $(13.37)^{* *}$ \\
\hline \multirow[t]{2}{*}{ Time in Business } & 0.01 & 0.017 & 0.003 & -0.003 & 0.011 & 0.017 \\
\hline & $(7.45)^{* *}$ & $(9.24)^{* *}$ & $(2.12)^{*}$ & $-(1.70)$ & $(10.66)^{* *}$ & $(15.11)^{* *}$ \\
\hline \multirow[t]{2}{*}{ Female } & 0.043 & -0.029 & 0.053 & 0.285 & 0.055 & -0.167 \\
\hline & $(1.42)$ & $-(0.60)$ & $(1.64)$ & $(7.63)^{* *}$ & $(2.19) *$ & $-(6.21)^{* *}$ \\
\hline \multirow[t]{2}{*}{ Head } & 0.104 & 0.067 & 0.098 & 0.002 & 0.034 & 0.022 \\
\hline & $(3.53)^{* *}$ & (1.43) & $(3.08)^{* *}$ & $(0.05)$ & $-(1.39)$ & $(0.85)$ \\
\hline \multirow[t]{2}{*}{ Npers } & 0.01 & 0.002 & 0.012 & -0.014 & -0.015 & 0.009 \\
\hline & $(2.11)^{*}$ & $-(0.31)$ & $(2.25)^{*}$ & $-2.08) *$ & $-(3.61)^{* *}$ & $(2.01)^{*}$ \\
\hline \multirow[t]{2}{*}{ Married } & -0.014 & 0.047 & -0.036 & -0.05 & 0.034 & -0.039 \\
\hline & $-(0.54)$ & $(1.16)$ & $-(1.30)$ & $-(1.57)$ & (1.61) & $-(1.69)$ \\
\hline \multirow[t]{2}{*}{ Age } & 0.011 & 0.043 & -0.002 & 0.024 & 0.03 & 0.015 \\
\hline & $(2.25)^{*}$ & $(5.50)^{* *}$ & $-(0.41)$ & $(3.49)^{* *}$ & $(7.71)^{* *}$ & $(3.70)^{* *}$ \\
\hline \multirow[t]{2}{*}{ Age2 } & 0.0000 & 0.0000 & 0.0000 & 0.0000 & 0.0000 & 0.0000 \\
\hline & $(3.85)^{* *}$ & $(5.78)^{* *}$ & (1.33) & $(4.13)^{* *}$ & $(6.42)^{* *}$ & $(4.43)^{* *}$ \\
\hline \multirow[t]{2}{*}{ Prim } & 0.076 & 0.009 & 0.087 & 0.061 & 0.112 & 0.023 \\
\hline & (1.94) & $(0.15)$ & $(2.08)^{*}$ & $(0.97)$ & $(3.51)^{* *}$ & $(0.70)$ \\
\hline \multirow[t]{2}{*}{$\mathrm{Sec}$} & 0.156 & 0.216 & 0.085 & 0.486 & 0.286 & 0.003 \\
\hline & $(3.78)^{* *}$ & $(3.30)^{* *}$ & $(1.91)$ & $(7.56)^{* *}$ & $(8.39)^{* *}$ & $(0.08)$ \\
\hline \multirow[t]{2}{*}{ High } & 0.205 & 0.415 & -0.01 & 0.809 & 0.547 & 0.013 \\
\hline & $(4.16)^{* *}$ & $(5.61)^{* *}$ & $-(0.18)$ & $(11.37)^{* *}$ & $(13.33)^{* *}$ & $(0.31)$ \\
\hline \multirow[t]{2}{*}{ Formal Credit } & & & & 0.30 & 0.15 & 0.20 \\
\hline & & & & $(6.12)^{* *}$ & $(3.68)^{* *}$ & $(5.29)^{* *}$ \\
\hline \multirow[t]{2}{*}{ Informal Credit } & & & & 0.16 & 0.06 & 0.23 \\
\hline & & & & $(3.49)^{* *}$ & $(1.97)^{*}$ & $(7.63)^{* *}$ \\
\hline \multirow[t]{2}{*}{ Training } & 0.28 & 0.27 & 0.16 & & 0.21 & 0.23 \\
\hline & $(7.22)^{* *}$ & $(5.58)^{* *}$ & $(3.66)^{* *}$ & & $(6.19)^{* *}$ & $(6.47)^{* *}$ \\
\hline \multirow[t]{2}{*}{ Taxes } & 0.11 & 0.17 & 0.05 & 0.16 & & 0.20 \\
\hline & $(4.86)^{* *}$ & $(5.13)^{* *}$ & $(2.10)^{*}$ & $(5.53)^{* *}$ & & $(9.66)^{* *}$ \\
\hline \multirow[t]{2}{*}{ Guild } & 0.23 & 0.17 & 0.19 & 0.22 & 0.20 & \\
\hline & $(9.64)^{* *}$ & $(5.17)^{* *}$ & $(7.29)^{* *}$ & $(6.66)^{* *}$ & $(9.10)^{* *}$ & \\
\hline \multirow[t]{2}{*}{ Constant } & -2.557 & -4.477 & -2.071 & -3.315 & -3.842 & -1.994 \\
\hline & $-(20.13)^{* *}$ & $-(21.37)^{* *}$ & $-(15.20)^{* *}$ & $-(18.31)^{* *}$ & $-(35.57)^{* *}$ & $-(17.88)^{* *}$ \\
\hline Observations & 35037 & 35037 & 35037 & 35037 & 35037 & 35037 \\
\hline Pseudo R2 & 0.1548 & 0.2247 & 0.1095 & 0.2363 & 0.2866 & 0.1821 \\
\hline Prob $>$ Chi2 & 0.000 & 0.000 & 0.000 & 0.000 & 0.000 & 0.000 \\
\hline
\end{tabular}

Notes: Estimation includes dummies by year, industry and state although they are not reported.

$\mathrm{z}$ values in (). * significant at $5 \%$; ** significant at $1 \%$ 
Table 3 - Profits, OLS.

\begin{tabular}{|c|c|c|c|}
\hline Covariates: & $H$ & $H, Z$ & $H, Z, F$ \\
\hline \multicolumn{4}{|l|}{ Profits (ENAMIN) } \\
\hline \multirow[t]{2}{*}{ New Credi } & 0.379 & 0.122 & 0.095 \\
\hline & $(0.020)^{\star \star}$ & $(0.019)^{\star \star}$ & $(0.019)^{\star \star}$ \\
\hline \multirow[t]{2}{*}{ Formal Credi } & 0.622 & 0.268 & 0.227 \\
\hline & $(0.032)^{\star *}$ & $(0.030)^{\star *}$ & $(0.030)^{\star \star}$ \\
\hline \multirow[t]{2}{*}{ Informal Credi } & 0.217 & 0.030 & 0.014 \\
\hline & $(0.024)^{\star \star}$ & $(0.023)^{\star \star}$ & $(0.022)$ \\
\hline \multirow[t]{2}{*}{ Training } & 0.298 & 0.112 & 0.073 \\
\hline & $(0.028)^{\star \star}$ & $(0.0$ & $(0.026)^{\star}$ \\
\hline \multirow[t]{2}{*}{ Taxes } & 0.626 & 0.310 & 0.298 \\
\hline & $(0.013)^{\star \star}$ & $(0.014)^{\star \star}$ & $(0.014)^{\star \star}$ \\
\hline \multirow[t]{2}{*}{ Guilc } & 0.335 & 0.130 & 0.099 \\
\hline & $(0.017)^{\star \star}$ & $(0.016)$ & $(0.016)^{\star \star}$ \\
\hline Covariates: & $H$ & $H, Z$ & $H, Z, F$ \\
\hline \multicolumn{4}{|l|}{ Income (ENEU) } \\
\hline \multirow[t]{2}{*}{ New Credit } & 0.255 & 0.090 & 0.072 \\
\hline & $(0.015)^{\star \star}$ & $(0.014)^{\star \star}$ & $(0.014)^{\star \star}$ \\
\hline \multirow[t]{2}{*}{ Formal Credi } & 0.419 & 0.193 & 0.165 \\
\hline & $(0.024)^{\star \star}$ & $(0.023)^{\star \star}$ & $(0.023)^{\star \star}$ \\
\hline \multirow[t]{2}{*}{ Informal Credi } & 0.152 & 0.030 & 0.019 \\
\hline & $(0.017)^{\star \star}$ & $(0.016)^{\star}$ & $(0.016)$ \\
\hline \multirow[t]{2}{*}{ Training } & 0.235 & 0.110 & 0.083 \\
\hline & $(0.021)^{\star *}$ & $(0.020)^{*}$ & $(0.020)^{\star}$ \\
\hline \multirow[t]{2}{*}{ Taxes } & 0.423 & 0.219 & 0.210 \\
\hline & $(0.010)^{\star \star x}$ & $(0.010)^{\star}$ & $(0.010)^{\star \star}$ \\
\hline \multirow[t]{2}{*}{ Guild } & 0.204 & 0.073 & 0.049 \\
\hline & $(0.012)^{\star \star}$ & $(0.012)^{\star \star}$ & $(0.012)^{x}$ \\
\hline
\end{tabular}

Notes: * significant at 5\%; ** significant at $1 \%$. 
Table 4 - Profits, ATT propensity score matching estimates different methods

\begin{tabular}{|c|c|c|c|c|c|c|}
\hline Matching on: & $P(H)$ & $P(H, Z)$ & $P(H, Z, F)$ & $P(H)$ & $P(H, Z)$ & $P(H, Z, F)$ \\
\hline Profits (ENAMIN) & \multicolumn{3}{|c|}{ Nearest neighbor } & \multicolumn{3}{|c|}{ Kernel } \\
\hline \multirow[t]{2}{*}{ New Credit } & 0.353 & 0.085 & 0.095 & 0.394 & 0.115 & 0.093 \\
\hline & $(0.041)^{\star \star}$ & $(0.032)^{\star \star}$ & $(0.032)^{\star \star}$ & $(0.023)^{\star *}$ & $(0.022)^{\star \star}$ & $(0.021)^{\star \star}$ \\
\hline \multirow[t]{2}{*}{ Formal Credit } & 0.611 & 0.250 & 0.209 & 0.734 & 0.331 & 0.313 \\
\hline & $(0.054)^{\star \star}$ & $(0.047)^{\star \star}$ & $(0.043)^{\star \star}$ & $(0.034)^{\star *}$ & $(0.033)^{\star \star}$ & $(0.029)^{\star \star}$ \\
\hline \multirow[t]{2}{*}{ Informal Credit } & 0.200 & -0.026 & -0.011 & 0.226 & 0.047 & 0.033 \\
\hline & $(0.051)^{\star \star}$ & $(0.035)$ & $(0.043)$ & $(0.022)^{\star \star}$ & $(0.022)^{\star}$ & $(0.027)$ \\
\hline \multirow[t]{2}{*}{ Training } & 0.307 & 0.124 & 0.085 & 0.325 & 0.163 & 0.121 \\
\hline & $(0.043)^{\star \star}$ & $(0.053)^{\star \star}$ & $(0.043)^{\star \star}$ & $(0.028)^{\star \star}$ & $(0.029)^{\star \star}$ & $(0.033)^{\star *}$ \\
\hline \multirow[t]{2}{*}{ Taxes } & 0.656 & 0.266 & 0.229 & 0.636 & 0.232 & 0.225 \\
\hline & $(0.020)^{\star \star}$ & $(0.022)^{\star \star}$ & $(0.024)^{\star \star}$ & $(0.016)^{\star \star}$ & $(0.018)^{\star \star}$ & $(0.021)^{\star *}$ \\
\hline \multirow[t]{2}{*}{ Guild } & 0.345 & 0.102 & 0.094 & 0.339 & 0.118 & 0.092 \\
\hline & $(0.026)^{\star \star}$ & $(0.025)^{\star \star}$ & $(0.026)^{\star \star}$ & $(0.020)^{\star \star}$ & $(0.018)^{\star \star}$ & $(0.016)^{\star \star}$ \\
\hline Income (ENEU) & \multicolumn{3}{|c|}{ Nearest neighbor } & \multicolumn{3}{|c|}{ Kernel } \\
\hline \multirow[t]{2}{*}{ New Credit } & 0.243 & 0.054 & 0.100 & 0.263 & 0.096 & 0.083 \\
\hline & $(0.023)^{\star \star}$ & $(0.023)^{\star \star}$ & $(0.022)^{\star \star}$ & $(0.014)^{\star *}$ & $(0.017)^{\star \star}$ & $(0.015)^{\star \star}$ \\
\hline \multirow[t]{2}{*}{ Formal Credit } & 0.382 & 0.153 & 0.177 & 0.503 & 0.257 & 0.251 \\
\hline & $(0.041)^{\star \star}$ & $(0.050)^{\star \star}$ & $(0.038)^{\star \star}$ & $(0.025)^{\star *}$ & $(0.023)^{\star \star}$ & $(0.025)^{\star \star}$ \\
\hline \multirow[t]{2}{*}{ Informal Credit } & 0.146 & 0.028 & 0.022 & 0.169 & 0.054 & 0.044 \\
\hline & $(0.031)^{\star \star}$ & (0.037) & $(0.028)$ & $(0.022)^{\star \star}$ & $(0.02)^{\star}$ & $(0.017)^{\star \star}$ \\
\hline \multirow[t]{2}{*}{ Training } & 0.246 & 0.126 & 0.075 & 0.253 & 0.140 & 0.113 \\
\hline & $(0.031)^{\star \star}$ & $(0.038)^{\star \star}$ & $(0.037)^{\star}$ & $(0.024)^{\star \star}$ & $(0.024)^{\star \star}$ & $(0.028)^{\star *}$ \\
\hline \multirow[t]{2}{*}{ Taxes } & 0.405 & 0.173 & 0.154 & 0.402 & 0.154 & 0.147 \\
\hline & $(0.016)^{\star \star}$ & $(0.015)^{\star \star}$ & $(0.016)^{\star \star}$ & $(0.011)^{\star \star}$ & $(0.014)^{\star \star}$ & $(0.015)^{\star \star}$ \\
\hline \multirow[t]{2}{*}{ Guild } & 0.198 & 0.055 & 0.045 & 0.199 & 0.062 & 0.044 \\
\hline & $(0.019)^{\star \star}$ & $(0.021)^{\star}$ & $(0.023)^{\star \star}$ & $(0.014)^{\star *}$ & $(0.013)^{\star \star}$ & $(0.016)^{\star \star}$ \\
\hline
\end{tabular}

Notes: Kernel based matching methods using Epanichnikov kernel and a fixed bandwidth of 0.06 Bootstrapping standard errors based in 50 replications with 100\% sampling. * significant at 5\%; ** significant at $1 \%$ assuming normality. 


\section{Table 5 - Profits, Treatment Effects Regression}

\begin{tabular}{|c|c|c|c|}
\hline Covariates: & $H$ & $H, Z$ & $H, Z, F$ \\
\hline \multicolumn{4}{|l|}{ Profits (ENAMIN) } \\
\hline \multirow[t]{2}{*}{ New Credit } & 0.313 & 0.362 & 0.280 \\
\hline & $(0.053)^{\star \star}$ & $(0.038)^{\star \star}$ & $(0.038)^{\star \star}$ \\
\hline \multirow{2}{*}{ Formal Credit } & 0.393 & 0.604 & 0.490 \\
\hline & $(0.253)$ & $(0.056)^{\star \star}$ & $(0.061)^{\star *}$ \\
\hline \multirow[t]{2}{*}{ Informal Credit } & 0.114 & 0.181 & 0.130 \\
\hline & $(0.068)$ & $(0.044)^{\star \star}$ & $(0.043)^{\star \star}$ \\
\hline \multirow[t]{2}{*}{ Training } & -0.176 & 0.021 & -0.199 \\
\hline & $(0.157)$ & $(0.142)$ & $(0.260)$ \\
\hline \multirow[t]{2}{*}{ Taxes } & 0.574 & 0.608 & 0.584 \\
\hline & $(0.037)^{\star \star}$ & $(0.027)^{\star \star}$ & $(0.028)^{\star \star}$ \\
\hline \multirow[t]{2}{*}{ Guild } & 0.073 & 0.219 & 0.089 \\
\hline & $(0.091)$ & $(0.042)^{\star \star}$ & $(0.052)$ \\
\hline \multirow{3}{*}{$\frac{\text { Income (ENEU) }}{\text { New Credit }}$} & $H$ & $H, Z$ & $H, Z, F$ \\
\hline & 0.114 & 0.204 & 0.133 \\
\hline & $(0.050)^{\star \star}$ & $(0.045)^{\star \star}$ & $(0.048)^{\star \star}$ \\
\hline \multirow[t]{2}{*}{ Formal Credit } & 0.238 & 0.333 & 0.188 \\
\hline & $(0.081)^{\star \star}$ & $(0.080)^{\star *}$ & $(0.086)^{*}$ \\
\hline \multirow[t]{2}{*}{ Informal Credit } & -0.037 & 0.084 & 0.048 \\
\hline & $(0.068)$ & $(0.061)$ & $(0.062)$ \\
\hline \multirow[t]{2}{*}{ Training } & 0.217 & 0.197 & 0.128 \\
\hline & $(0.049)^{\star \star}$ & $(0.047)^{\star \star}$ & $(0.048)^{\star \star}$ \\
\hline \multirow[t]{2}{*}{ Taxes } & 0.161 & 0.451 & 0.429 \\
\hline & $(0.102)$ & $(0.033)^{\star \star}$ & $(0.035)^{\star \star}$ \\
\hline \multirow[t]{2}{*}{ Guild } & -0.191 & -0.080 & -0.263 \\
\hline & $(0.069)^{\star \star}$ & $(0.094)$ & $(0.082)^{\star \star}$ \\
\hline
\end{tabular}


Table 6 - Income growth statistics

\begin{tabular}{l|cc}
\hline \hline & \multicolumn{2}{|c}{ Real Income Growth (ENEU) } \\
\hline Treatment & Treated & Non-treated \\
\hline New Credit & $-9.8 \%$ & $-4.9 \%$ \\
Formal Credit & $-18.2 \%$ & $-5.2 \%$ \\
Informal Credit & $-8.1 \%$ & $-5.4 \%$ \\
Taxes & $-8.4 \%$ & $-4.4 \%$ \\
Training & $-11.5 \%$ & $-5.4 \%$ \\
Guild & $-8.9 \%$ & $-5.1 \%$ \\
\hline \multicolumn{2}{l}{ Notes: ENEU-ENAMIN small sample. Survivors only. }
\end{tabular}


Table 7 - Income growth, OLS

\begin{tabular}{r|ccc}
\hline \hline Covariates: & $H$ & $H, Z$ & $H, Z, F$ \\
\hline New Credit & -0.091 & -0.098 & -0.095 \\
Formal Credit & $(0.039)^{\star \star}$ & $(0.041)^{\star}$ & $(0.040)^{\star}$ \\
& -0.081 & -0.090 & -0.083 \\
Informal Credit & $(0.069)$ & $(0.071)$ & $(0.069)$ \\
& -0.094 & -0.099 & -0.098 \\
Training & $(0.045)^{\star}$ & $(0.045)^{\star}$ & $(0.045)^{\star}$ \\
& -0.056 & -0.061 & -0.047 \\
Taxes & $(0.070)$ & $(0.070)$ & $(0.070)$ \\
& 0.004 & -0.006 & 0.000 \\
Guild & $(0.032)$ & $(0.034)$ & $(0.035)$ \\
& -0.020 & -0.027 & -0.021 \\
& $(0.039)$ & $(0.039)$ & $(0.039)$ \\
\hline \hline
\end{tabular}

Notes: * significant at 5\%; ** significant at 1\%. 
Table 8 - Income growth, ATT propensity score matching estimates different methods

\begin{tabular}{r|ccc|ccc}
\hline \hline Matching on: & \multicolumn{7}{|c|}{$P(H)$} & $P(H, Z)$ & $P(H, Z, F)$ & $P(H)$ & $P(H, Z)$ & $P(H, Z, F)$ \\
\hline New Credit & -0.115 & -0.094 & -0.105 & -0.107 & -0.106 & -0.102 \\
& $(0.073)$ & $(0.056)$ & $(0.061)$ & $(0.038)^{\star \star}$ & $(0.040)^{\star \star}$ & $(0.039)^{\star \star}$ \\
Formal Credit & -0.105 & -0.074 & -0.020 & -0.102 & -0.104 & -0.095 \\
& $(0.114)$ & $(0.109)$ & $(0.106)$ & $(0.078)$ & $(0.063)$ & $(0.083)$ \\
Informal Credit & -0.152 & -0.038 & -0.016 & -0.095 & -0.095 & -0.093 \\
& $(0.059)^{\star \star}$ & $(0.066)$ & $(0.066)$ & $(0.050)$ & $(0.051)$ & $(0.045)^{\star}$ \\
Training & -0.086 & -0.115 & 0.072 & -0.054 & -0.053 & -0.062 \\
& $(0.104)$ & $(0.090)$ & $(0.096)$ & $(0.066)$ & $(0.064)$ & $(0.072)$ \\
Taxes & -0.030 & -0.031 & -0.075 & 0.001 & -0.039 & -0.032 \\
& $(0.043)$ & $(0.058)$ & $(0.055)$ & $(0.030)$ & $(0.046)$ & $(0.052)$ \\
& 0.023 & 0.003 & -0.156 & -0.025 & -0.036 & -0.033 \\
& $(0.058)$ & $(0.054)$ & $(0.052)^{\star *}$ & $(0.044)$ & $(0.041)$ & $(0.038)$ \\
\hline \hline
\end{tabular}

Notes: Kernel based matching methods using Epanichnikov kernel and a fixed bandwidth of 0.06 .

Bootstrapping standard errors based in 50 replications with 100\% sampling. * significant at 5\%; **

significant at $1 \%$ assuming normality. 
Table 9 - Income growth, Treatment Effects Regression

\begin{tabular}{r|ccc|}
\hline Covariates: & $H$ & $H, Z$ & $H, Z, F$ \\
\hline New Credit & -0.102 & -0.064 & -0.068 \\
& $(0.114)$ & $(0.111)$ & $(0.116)$ \\
Formal Credit & 0.078 & 0.171 & 0.134 \\
& $(0.252)$ & $(0.203)$ & $(0.216)$ \\
Informal Credit & -0.095 & -0.122 & -0.125 \\
& $(0.116)$ & $(0.110)$ & $(0.112)$ \\
Training & 0.003 & -0.065 & -0.080 \\
& $(0.254)$ & $(0.191)$ & $(0.208)$ \\
Taxes & -0.039 & 0.088 & 0.114 \\
& $-(0.057)$ & $(0.143)$ & $(0.144)$ \\
Guild & 0.078 & 0.182 & 0.207 \\
& $(0.132)$ & $(0.121)$ & $(0.120)$ \\
\hline \hline
\end{tabular}

Notes: * significant at 5\%; ** significant at 1\%.. MLE treatment regression. 
Table 10 - Firm Survival likelihood

\begin{tabular}{l|cc}
\hline \hline & \multicolumn{2}{|c}{ Survival likelihood } \\
\hline Treatment & Treated & Non-treated \\
\hline New Credit & $80.3 \%$ & $72.7 \%$ \\
Formal Credit & $85.7 \%$ & $73.5 \%$ \\
Informal Credit & $78.9 \%$ & $73.3 \%$ \\
Taxes & $82.6 \%$ & $70.0 \%$ \\
Training & $77.6 \%$ & $73.7 \%$ \\
Guild & $82.7 \%$ & $72.2 \%$ \\
\hline \hline
\end{tabular}

Notes: ENEU-ENAMIN small sample. 
Table 11 - Firm survival, ATT propensity score matching estimates - different methods

\begin{tabular}{|c|c|c|c|c|c|c|}
\hline Matching on: & $P(H)$ & $P(H, Z)$ & $P(H, Z, F)$ & $P(H)$ & $P(H, Z)$ & $P(H, Z, F)$ \\
\hline Income growth & \multicolumn{3}{|c|}{ Nearest neighbor } & \multicolumn{3}{|c|}{ Kernel } \\
\hline \multirow[t]{2}{*}{ New Credit } & 0.048 & 0.069 & 0.023 & 0.027 & 0.042 & 0.022 \\
\hline & $(0.024)^{\star}$ & $(0.022)^{\star \star}$ & $(0.023)$ & $(0.015)$ & $(0.015)^{\star \star}$ & $(0.018)$ \\
\hline \multirow[t]{2}{*}{ Formal Credit } & 0.009 & 0.075 & -0.005 & 0.035 & 0.061 & 0.032 \\
\hline & $(0.042)$ & $(0.041)$ & $(0.040)$ & $(0.026)$ & $(0.021)^{\star \star *}$ & $(0.028)$ \\
\hline \multirow[t]{2}{*}{ Informal Credit } & 0.022 & 0.040 & -0.006 & 0.023 & 0.035 & 0.020 \\
\hline & $(0.030)$ & $(0.029)$ & $(0.033)$ & $(0.020)$ & $(0.017)^{\star}$ & $(0.015)$ \\
\hline \multirow[t]{2}{*}{ Training } & -0.003 & 0.009 & -0.028 & 0.006 & 0.014 & 0.004 \\
\hline & $(0.044)$ & $(0.037)$ & $(0.049)$ & $(0.024)$ & $(0.023)$ & $(0.034)$ \\
\hline \multirow[t]{2}{*}{ Taxes } & 0.051 & 0.090 & 0.036 & 0.051 & 0.071 & 0.044 \\
\hline & $(0.022)^{\star}$ & $(0.020)^{\star \star}$ & $(0.017)^{\star}$ & $(0.014)^{\star \star}$ & $(0.014)^{\star \star}$ & $(0.019)^{\star}$ \\
\hline \multirow[t]{2}{*}{ Guild } & 0.033 & 0.033 & 0.019 & 0.025 & 0.042 & 0.018 \\
\hline & $(0.023)$ & $(0.025)$ & $(0.024)$ & $(0.019)$ & $(0.017)^{\star}$ & $(0.014)$ \\
\hline
\end{tabular}

Notes: Kernel based matching methods using Epanichnikov kernel and a fixed bandwidth of 0.06 .

Bootstrapping standard errors based in 50 replications with 100\% sampling. * significant at 5\%; ** significant at 1\% assuming normality. 